San Jose State University

SJSU ScholarWorks

Mineta Transportation Institute Publications

$2-2020$

\title{
A Smart Growth \& Equity Framework and Tool for Measuring, Understanding, and Realizing Transportation Land Use Coordination for Sustainability, Livability, and Equity
}

\author{
Bruce Appleyard \\ San Diego State University \\ Chris Allen \\ Jonathan Stanton
}

Follow this and additional works at: https://scholarworks.sjsu.edu/mti_publications

Part of the Environmental Engineering Commons, and the Transportation Engineering Commons

\section{Recommended Citation}

Bruce Appleyard, Chris Allen, and Jonathan Stanton. "A Smart Growth \& Equity Framework and Tool for Measuring, Understanding, and Realizing Transportation Land Use Coordination for Sustainability, Livability, and Equity" Mineta Transportation Institute Publications (2020). https://doi.org/10.31979/ mti.2020.1899

This Report is brought to you for free and open access by SJSU ScholarWorks. It has been accepted for inclusion in Mineta Transportation Institute Publications by an authorized administrator of SJSU ScholarWorks. For more information, please contact scholarworks@sjsu.edu. 
SJSU

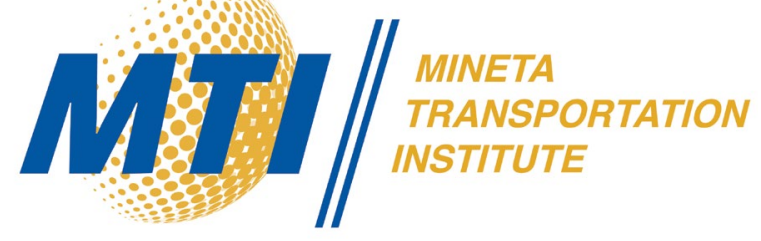

A Smart Growth \& Equity Framework and Tool for Measuring, Understanding, and Realizing Transportation Land Use Coordination for Sustainability, Livability, and Equity

Bruce Appleyard, PhD

Chris Allen

Jonathan Stanton

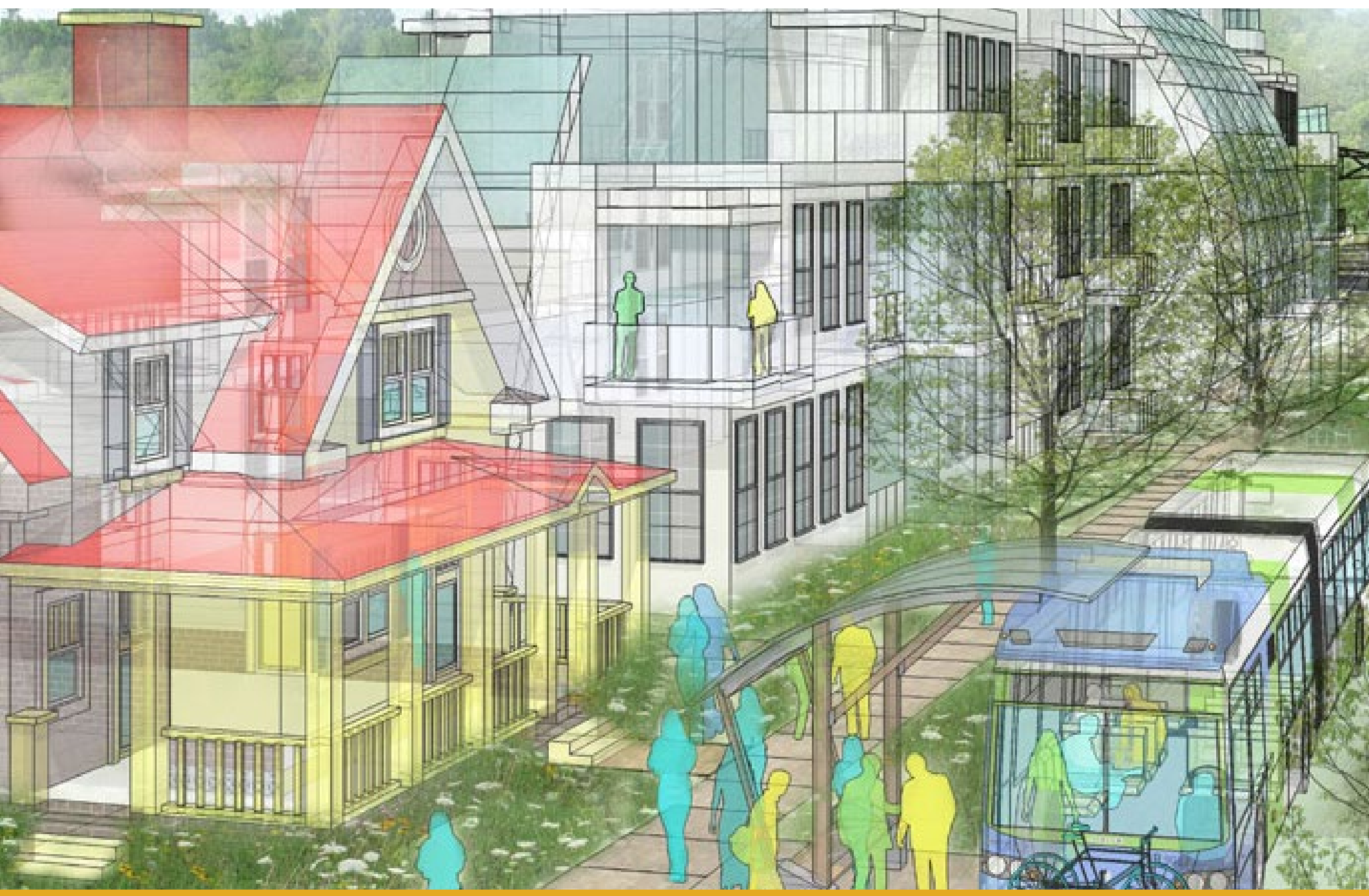




\section{MINETA TRANSPORTATION INSTITUTE \\ LEAD UNIVERSITY OF \\ Mineta Consortium for Transportation Mobility}

Founded in 1991, the Mineta Transportation Institute (MTI), an organized research and training unit in partnership with the Lucas College and Graduate School of Business at San José State University (SJSU), increases mobility for all by improving the safety, efficiency, accessibility, and convenience of our nation's transportation system. Through research, education, workforce development, and technology transfer, we help create a connected world. MTI leads the four-university Mineta Consortium for Transportation Mobility, a Tier I University Transportation Center funded by the U.S. Department of Transportation's Office of the Assistant Secretary for Research and Technology (OST-R), the California Department of Transportation (Caltrans), and by private grants and donations.

MTl's transportation policy work is centered on three primary responsibilities:

\section{Research}

MTI works to provide policy-oriented research for all levels of government and the $P$ rivate sector to foster the development of optimum surface transportation systems. Research areas include: bicycle and pedestrian issues; financing public and private sector transportation improvements; intermodal connectivity and integration; safety and security of transportation systems; sustainability of transportation systems; transportation / land use / environment; and transportation planning and policy development. Certified Research Associates conduct the research. Certification requires an advanced degree, generally a Ph.D., a record of academic publications, and professional references. Research projects culminate in a peer-reviewed publication, available on TransWeb, the MTI website (http://transweb.sjsu.edu).

\section{Education}

The Institute supports education programs for students seeking a career in the development and operation of surface transportation systems. MTI, through San José State University, offers an AACSBaccredited Master of Science in Transportation Management and graduate certificates in Transportation Management,Transportation Security, and High-Speed Rail Management that serve to prepare the nation's transportation managers for the 2 I st century. With the active assistance of the California Department of Transportation (Caltrans), MTI delivers its classes over a state-of-the-art videoconference network throughout the state of California and via webcasting beyond, allowing working transportation professionals to pursue an advanced degree regardless of their location. To meet the needs of employers seeking a diverse workforce, MTl's education program promotes enrollment to under-represented groups.

\section{Information and Technology Transfer}

MTI utilizes a diverse array of dissemination methods and media to ensure research results reach those responsible for managing change. These methods include publication, seminars, workshops, websites, social media, webinars, and other technology transfer mechanisms. Additionally, MTI promotes the availability of completed research to professional organizations and journals and works to integrate the research findings into the graduate education program.MTI's extensive collection of transportation- related publications is integrated into San José State University's world-class Martin Luther King, Jr. Library.

\section{Disclaimer}

The contents of this report reflect the views of the authors, who are responsible for the facts and accuracy of the information presented herein. This document is disseminated in the interest of information exchange. The report is funded, partially or entirely, by a grant from the U.S. Department of Transportation's University Transportation Centers Program. This report does not necessarily reflect the official views or policies of the U.S. government, State of California, or the Mineta Transportation Institute, who assume no liability for the contents or use thereof. This report does not constitute a standard specification, design standard, or regulation. 
REPORT 20-02

\title{
A SMART GROWTH \& EQUITY FRAMEWORK AND TOOL FOR MEASURING, UNDERSTANDING, AND REALIZING TRANSPORTATION LAND USE COORDINATION FOR SUSTAINABILITY, LIVABILITY, AND EQUITY
}

\author{
Bruce Appleyard, PhD \\ Chris Allen \\ Jonathan Stanton
}

February 2020

A publication of

Mineta Transportation Institute

Created by Congress in 1991

College of Business

San José State University

San José, CA 95192-0219 


\section{TECHNICAL REPORT DOCUMENTATION PAGE}

1. Report No. 20-02

4. Title and Subtitle

A Smart Growth \& Equity Framework and Tool for Measuring, Understanding, and Realizing Transportation Land Use Coordination for Sustainability, Livability, and Equity

7. Authors

Bruce Appleyard, PhD

Chris Allen

Jonathan Stanton

9. Performing Organization Name and Address

Mineta Transportation Institute

College of Business

San José State University

San José, CA 95192-0219

12. Sponsoring Agency Name and Address

U.S. Department of Transportation

Office of the Assistant Secretary for

Research and Technology

University Transportation Centers Program

1200 New Jersey Avenue, SE

Washington, DC 20590
2. Government Accession No.

3. Recipient's Catalog No.

5. Report Date

February 2020

6. Performing Organization Code

8. Performing Organization Report CA-MTI-1899

10. Work Unit No.

11. Contract or Grant No.

13. Type of Report and Period Covered Final Report

14. Sponsoring Agency Code

15. Supplemental Notes

DOI: $10.31979 / \mathrm{mti} .2020 .1899$

16. Abstract

The coordination and integration of transportation and land use (also known as "smart growth") has been a long-standing goal for planning and engineering professionals, but to this day remains an elusive concept to realize. As this approach is a widely recognized as key to achieving sustainable, livable, and equitable (SLE) outcomes for individuals and society, a key aim of this report is to instill the coordination of transportation and land use into practice by the collection of key actors and agents (MPOs, DOTs, and local land use authorities, etc.) through new measurement and policy guidance frameworks and tools. A fundamental assumption of this report is that frameworks are needed first to help guide the use of tools to measure and understand urban quality, and then inform policy decisions toward realizing SLE outcomes. Along these lines, this report provides a review of current literature and practice related to measuring and understanding the integration of transportation and land use through the lenses of sustainability, livability, and equity (SLE), specifically focusing on efforts to operationalize the Livability Principles of the 2009 HUD/DOT/EPA Partnership for Sustainable Communities and Caltrans' Smart Mobility Framework. Specifically, this report builds on the use of various principles, performance measures, and place typology frameworks, along with current mapping and Planning Support Tools (PSTs) in order to develop a framework to:

a) Measure SLE urban quality performance urban places

b) Understand what this SLE performance means in terms of how to respond with policies

c) Provide guidance on how to enact policies to realize more robust transportation land use integration (smart growth) to achieve SLE outcome for society.

With this knowledge and understanding we then go into a discussion of tools and metrics and how they can be used. For illustration purposes, this report uses the Smart Growth \& Social Equity Calculator (https://smartgrowthcalculator.netlify.com/) - an online tool designed to make key data easily available to all stakeholders so they can more readily make coordinated decisions to that will lead to a more robust integration between transportation and land use. Specifically, the SGE Calculator can help with: climate action planning, VMT analysis related to new CEQA regulations under SB 743 that move us away from LOS, and how to coordinate transportation \& land use across the spectrum, from community NIMBY discourses to regional and state transportation planning.

\section{Key Words}

Smart growth, livability, planning support tools, transportation, land use, housing, climate action planning.

19. Security Classif. (of this report) Unclassified

\section{Distribution Statement}

No restrictions. This document is available to the public through

The National Technical Information Service, Springfield, VA 22161
21. No. of Pages
43
22. Price
Unclassified

Form DOT F 1700.7 (8-72) 


\title{
Copyright $\odot 2020$ \\ by Mineta Transportation Institute \\ All rights reserved
}

DOI: 10.31979/mti.2020.1899

\author{
Mineta Transportation Institute \\ College of Business \\ San José State University \\ San José, CA 95192-0219 \\ Tel: (408) 924-7560 \\ Fax: (408) 924-7565 \\ Email: mineta-institute@sjsu.edu
}

transweb.sjsu.edu 


\section{ACKNOWLEDGMENTS}

The authors wish to thank the US Department of Transportation. We would also like to acknowledge the work of particular researchers and collaborators, including Alexander Frost, Eduardo Cordova, David Reinke, Caleb Schroeder, and Annapurna Singh.

The authors thank Editing Press, for editorial services, as well as MTI staff, including Executive Director Karen Philbrick, PhD; Deputy Executive Director Hilary Nixon, PhD; Graphic Designer Alverina Eka Weinardy; and Executive Administrative Assistant Jill Carter. 


\section{TABLE OF CONTENTS}

I. Livability and Smart Growth Equity Calculators: New Tools for Measuring Understanding and Realizing Smart Growth for

Sustainability, Livability, and Equity

Introduction and Background

The Livability and Smart Growth Equity Calculators 1

Livability as Access to Opportunities to Improve/Maintain one's desired quality of life $\quad 2$

II. Smart Growth Equity Calculator: Overview 5

(https://smartgrowthcalculator.netlify.com/ or http://bit.ly/SmartGrowthEquity) 5

$\begin{array}{ll}\text { The Data of the SGE Calculator } & 6\end{array}$

$\begin{array}{ll}\text { Why VMT is the First Thing Shown on the Smart Growth Equity Calculator? } & 7\end{array}$

Using VMT Toward Regional Land Use Planning to Support Regional

Transportation Plans 8

The Uses of the SGE Calculator $\quad 8$

TOD Atlas: The Equity of Urban QUality Around Train Stations 9

III. The Smart Growth Equity (SGE) Calculator User Guide 10

IV. The SGE Calculator in Action: Illustrative Examples 14

New Environmental Regulations for Project Development review: Using

VMT Instead of Level of Service 14

Climate Action Planning Case Study 16

Supporting Sustainable AND Equitable Housing Plans 18

SGE AND SGE CALCULATORS IN RESEARCH 22

V. A Potential Application for a Future of Transportation Innovation, Disruption, and Automation 24

VI. New Ways to Explore Street Designs $\quad 28$

$\begin{array}{lr}\text { VII. Conclusion } & 29\end{array}$

$\begin{array}{ll}\text { Appendix: Performance Measures } & 30\end{array}$

$\begin{array}{ll}\text { Bibliography } & 33\end{array}$

About the Principal Investigator 42

$\begin{array}{ll}\text { Peer Review } & 43\end{array}$ 


\section{LIST OF FIGURES}

1. Operationalizing the 2009 EPA Livability Principles of the HUD/USDOT/ EPA Sustainable Communities Partnership

2. Smart Growth/Livability Calculator for the Handbook for Building Livable Transit Corridors

3. The Smart Growth Calculator Showing an Example of How the

Performance Radar Graphic from the Livability Calculator Can Be

Merged with the Smart Growth Calculator

4. The Location Efficient/Neighborhood Design

5. Light Rail Station performance and $1 / 4-$ mile overlay in the Smart Growth Calculator 9

6. Urban Quality Metrics Column Showing VMT

7. Selecting Different Urban Quality Metrics

8. Selecting Areas in the Smart Growth Calculator

9. Locating Layer Selection

10. Toggle Layers

11. SB 743 Visualization and Examples in Smart Growth Calculator

12. Smart Growth Calculator Used in San Diego College Area Community Plan

13. Using the Smart Growth Calculator for Climate Action Planning

14. Dr. Appleyard Featured on KPBS San Diego

15. Smart Growth Calculator Used for Community Planning

16. Students and Community Members Using the Smart Growth Calculator to Guide Discussion

17. Smart Growth Calculator with Transit and Disadvantaged Communities Overlay 23

18. Transportation and Land Use Coordination Performance Pyramid for Livability, Sustainability, and Equity -Prioritizing

19. Smart Growth Calculator Used to Compare Different Transit Systems

20. An Evolution of an Urban Street Section in an Era of AVs 


\section{LIST OF TABLES}

1. The 12 Metrics of the Operationalized Livability Principles of the 2009 HUD/USDOT/EPA Sustainable Communities Partnership

2. Data Used in the Smart Growth \& Social Equity Calculator 6

3. Carbon Emissions for select neighborhoods and housing developments 18

4. Recommended Performance Metrics 


\section{LIVABILITY AND SMART GROWTH EQUITY CALCULATORS: NEW TOOLS FOR MEASURING UNDERSTANDING AND REALIZING SMART GROWTH FOR SUSTAINABILITY, LIVABILITY, AND EQUITY}

\section{INTRODUCTION AND BACKGROUND}

This section provides a brief overview of the development of a specific set of frameworks and tools by the research team designed to a) help agencies evaluate the strengths and weaknesses of transportation land use coordination, and then $b$ ) help determine the best policies going forward to realize a stronger TLU coordination.

Transportation and Land-use Coordination (TLC) is a widely recognized approach for achieving what is often referred to as "smart growth." However, absent substantial institutional changes enabling transportation, land use, and these other disciplines to truly work in a coordinated fashion, we are left to seek methods with data, performance measures, and policy guidance frameworks to achieve a more holistic TLC approach so professionals and the public can make more informed decisions about to provide people with the necessary opportunities so they can achieve more sustainable, livable, and equitable outcomes for themselves and society as a whole.

In response, discusses the development of two planning support tools (PSTs) and their underlying framework and measures to help an array of stakeholders to better understand the sustainability, livability, and equity performance of urban places so they can make more informed decisions for how communities and regions should grow and evolve, now and in the future.

\section{THE LIVABILITY AND SMART GROWTH EQUITY CALCULATORS}

The Smart Growth/Livability Calculator for the Handbook for Building Livable Transit Corridors (http://bit.ly/2dP8rsT) builds on the foundations of the Six "Livability Principles" of the 2009 HUD, USDOT, and EPA Sustainable Communities Partnership by operationalizing them through a focused set of transportation, land use and quality of life metrics based on. As these are essentially restatements of EPA's 10 Smart Growth Principles, this is an effective planning support tool for measuring urban quality, as it relates to such concepts as Smart Growth and New Urbanism, as well as the associated sustainability, livability and equity outcomes.

Smart Growth Livability Performance is currently assessed by operationalizing the six HUD/EPA/USDOT principles, as shown in the Figure below, as follows:

- High-quality transit, walking, and bicycling opportunities,

- Healthy, safe \& walkable transit corridor neighborhoods,

- Vibrant \& accessible community, cultural \& recreational opportunities, 
- Accessible social \& government services,

- Transit-accessible economic opportunities, and

- Mixed income housing near transit (this currently supports the social equity principle, which measures housing affordability and income diversity).

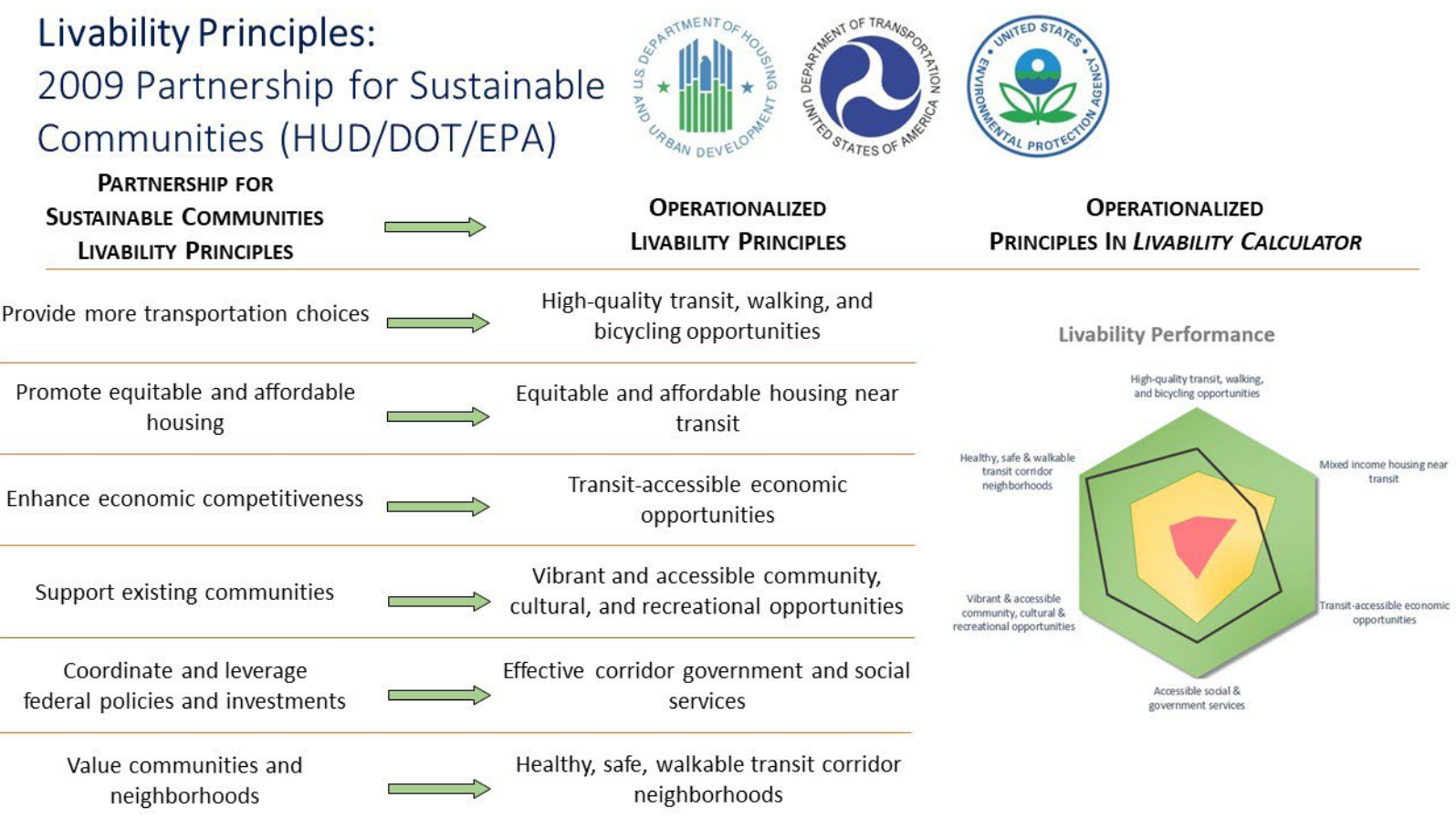

Figure 1. Operationalizing the 2009 EPA Livability Principles of the HUD/USDOT/ EPA Sustainable Communities Partnership

\section{LIVABILITY AS ACCESS TO OPPORTUNITIES TO IMPROVE/MAINTAIN ONE'S DESIRED QUALITY OF LIFE}

As discussed earlier in the section on Livability Ethics, Equity, and Justice, Smart Growth/ Livability Performance are suggested by the authors to be framed by measuring people's access to livability opportunities to improve and maintain one's desired quality of life. Therefore, the Smart Growth/Livability Calculator currently assessed by operationalizing the Six HUD/EPA/USDOT principles, as shown in the Figure above. From left to right are the original Livability Principles, the operationalized Livability Calculator Principles, and an example of a radar graphic readout from the Smart Growth/Livability Calculator itself.

In the development of the Handbook and Calculator, the authors have gathered an extensive array of geo-spatial data to explore the relationships between the measures of urban quality used and a host of quality of life outcomes measures. For this study, a California statewide database of built environment characteristics and sustainability performance metrics was created for 8,043 census tracts. 


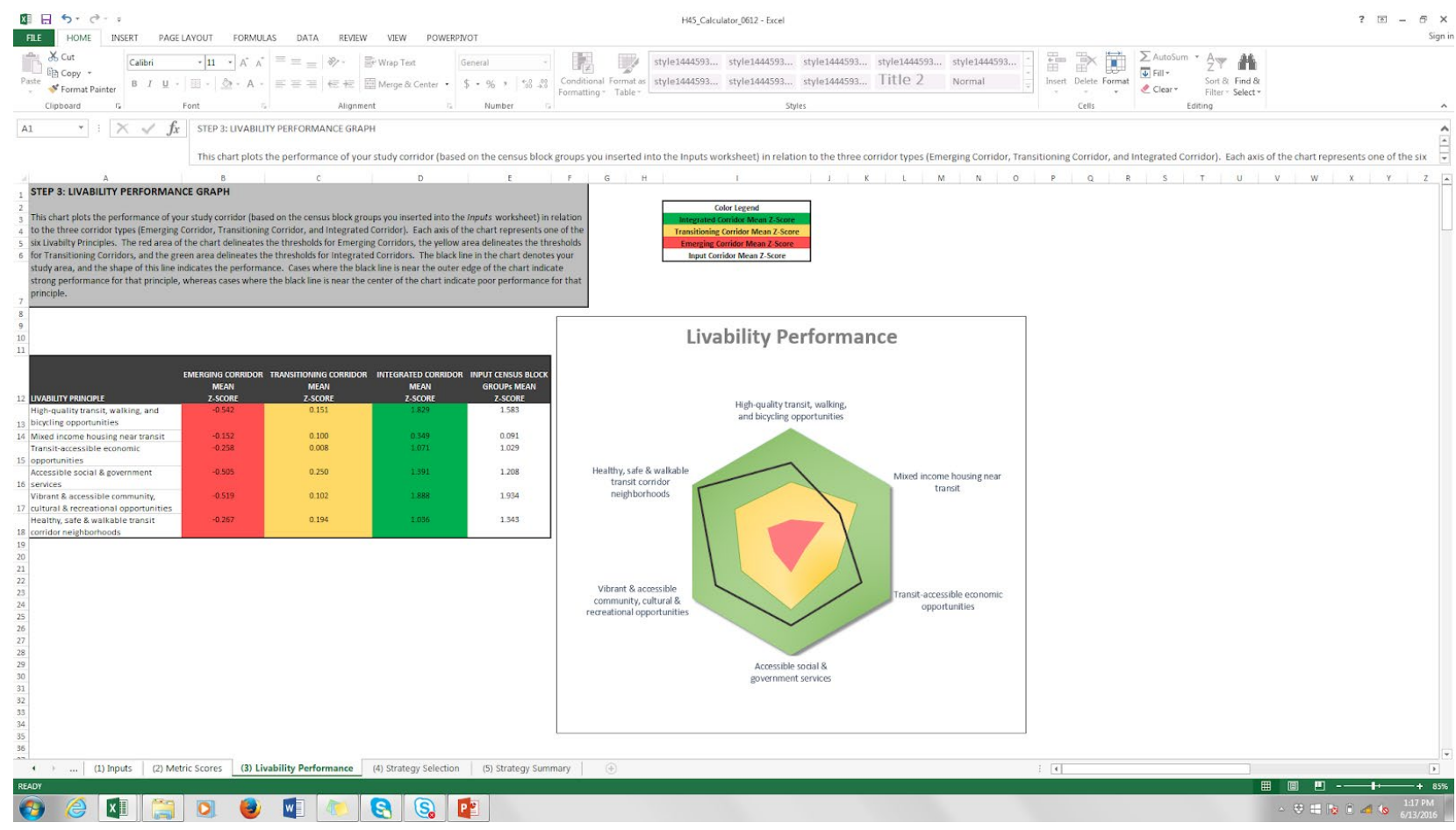

\section{Figure 2. Smart Growth/Livability Calculator for the Handbook for Building Livable Transit Corridors (http://bit.ly/2dP8rsT)}

In the development of the Handbook and Calculator, an extensive array of geo-spatial data was gathered to explore the relationships between our measures of urban quality and a host quality of life outcome measures. The table below shows the 12 metrics of the operationalized Livability Principles of the 2009 HUD/USDOT/EPA Sustainable Communities Partnership.

Table 1. The 12 Metrics of the Operationalized Livability Principles of the 2009 HUD/USDOT/EPA Sustainable Communities Partnership

\begin{tabular}{lll}
\hline \multicolumn{1}{c}{$\begin{array}{c}\text { Transit Corridor Livability } \\
\text { Principles }\end{array}$} & \multicolumn{1}{c}{ Metric } & \multicolumn{1}{c}{ Data Source(s) } \\
\hline $\begin{array}{l}\text { High-quality transit, walking, and } \\
\text { bicycling opportunities }\end{array}$ & Transit jobs accessibility & $\begin{array}{l}\text { EPA's Smart Locations Data Set } \\
\text { (SLD) 2013 }\end{array}$ \\
& & D5br: Jobs within 45-minute transit \\
& & commute, distance decay (walk \\
& & \\
& & network travel time) weighted \\
& SLD \\
& Transit service coverage & D4c: Aggregate frequency of transit \\
& (aggregate frequency of transit & service within 0.25 mile of block group \\
& service per sq. mile) & boundary per hour during evening \\
& & peak period \\
\hline
\end{tabular}




\section{Transit Corridor Livability Principles}

Mixed-income housing near transit
Metric

Housing unaffordability (percent of income spent for housing)

Income diversity (variance from regional median household income)
Transit-accessible economic opportunities
Jobs density (employees/acre)

Retail jobs density (retail employees/acre)

\section{Data Source(s)}

HUD's 2012 Housing Affordability Index Data Set (HAI)

hh_type1_: housing cost as a percent of income for the regional typical household, defined as: Avg HH size for region, median income for region, average number of commuters per $\mathrm{HH}$ for region

National Historical Geographic Information System (NHGIS), 2010 Census ID B19013: Coefficient of variance of block group median household income compared to either the metro area or the state median; closer to zero means less diversity, closer to one means more

\section{SLD}

D1c: Gross employment density employees (jobs)/acre on unprotected land, 2013

SLD

D1c_Ret10: Gross retail employment density employees (jobs)/acre on unprotected land

Accessible social \& government services

Transit ridership balance of flows

Transit agency route/line data Inbound (to CBD) daily boardings/ inbound daily alightings

Health care opportunities (health care employees/acre)

SLD

D1c8_Hlth10: Gross health care (8tier) employment density employees (jobs)/acre on unprotected land

Vibrant \& accessible community, cultural \& recreational opportunities
Population density (population/ acre)

Access to culture \& arts (\# corridor entertainment employees/acre)

Pedestrian environment (intersection density)

\section{SLD}

D1b: Gross population density (people/acre) on unprotected land

\section{SLD}

D1c_Ent10: Gross entertainment employment density employees (jobs)/ acre on unprotected land

Healthy, safe \& walkable transit corridor neighborhoods

\section{SLD}

D3bmm4: Intersection density in terms of multi-modal intersections having four or more legs per square mile

Pedestrian collisions per 100,000 pedestrians
Transportation Injury Mapping System (TIMS) 2010

Pedestrian collisions per 100,000 pedestrians 


\section{SMART GROWTH EQUITY CALCULATOR: OVERVIEW}

\section{(HTTPS://SMARTGROWTHCALCULATOR.NETLIFY.COM/ OR HTTP://BIT.LYI SMARTGROWTHEQUITY)}

Building on this earlier work, Dr. Appleyard and his student research team developed an online Smart Growth Equity (SGE) Calculator (http://bit.ly/SmartGrowthEquity) using similar data and metrics gathered for the entire U.S. for the development of the Livability Calculator. One of the goals was to make the visualization of these data and calculations more accessible for key stakeholders (practitioners, members of the public, and politicians) to use towards analysis and policy guidance for a number of different transportation and land use coordination issues, including climate action planning, corridor planning, new housing initiatives (such as SB 50), and new environmental regulations under SB 743, which allows for environmental streamlining of significant developments in areas that are $15 \%$ below regional averages for per capita Vehicle Miles Travelled (VMT) as opposed to Level of Service (the importance of which is discussed in more detail below). The SGE Calculator can even be used to determine the performance of future transportation scenarios, including but not limited to those future scenarios related to Autonomous Vehicles (AVs) and Mobility as a Service (MaaS).

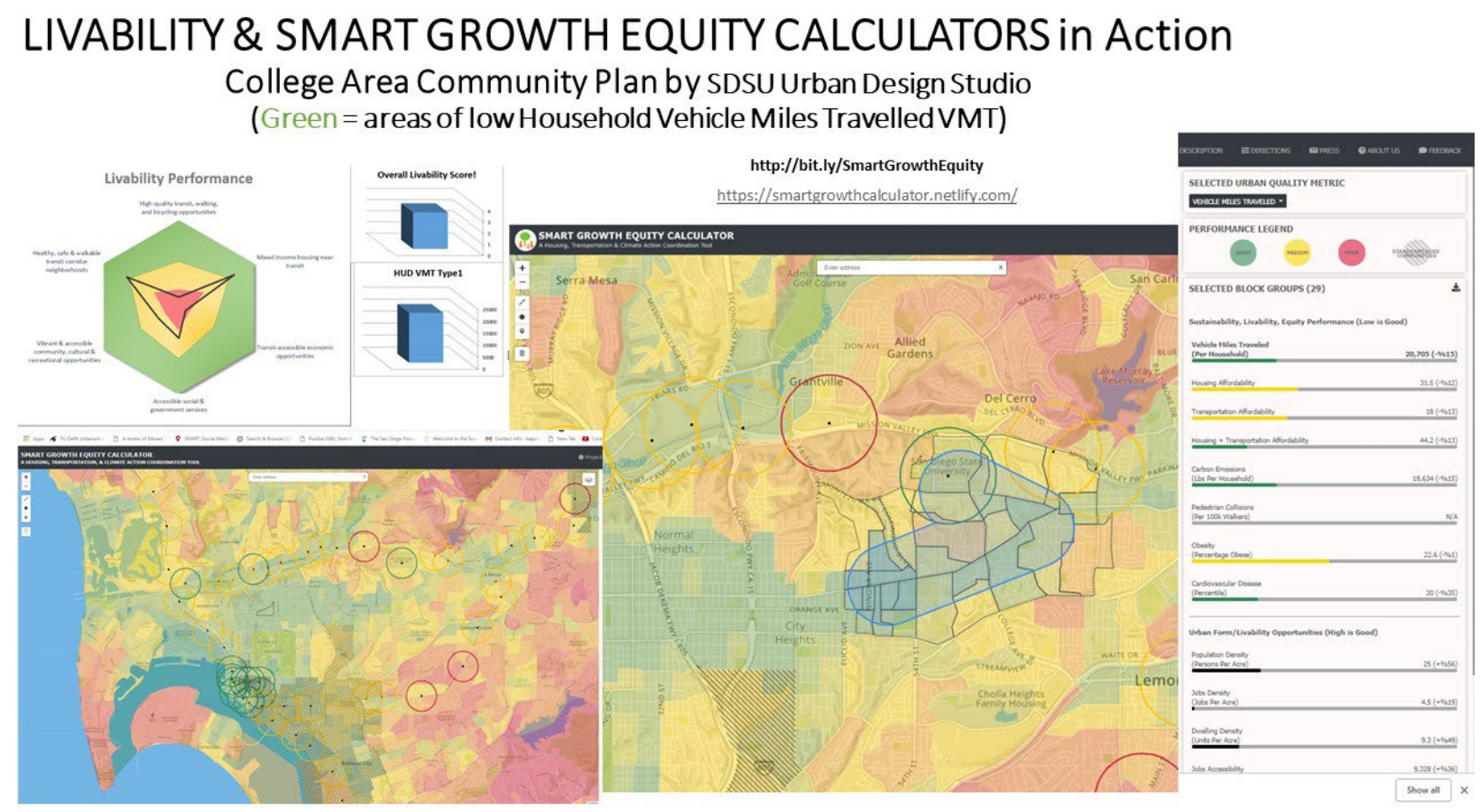

Figure 3. The Smart Growth Calculator Showing an Example of How the Performance Radar Graphic from the Livability Calculator Can Be Merged with the Smart Growth Calculator

Upon hovering the mouse cursor over an area, percentages of VMT will be displayed on the right side, showing how much an area is above or below the regional average. Along these lines, the SGE Calculator can also be used for new housing initiatives. For example, it can be used for new housing initiatives proposing to up-zone areas around transit (like SB 50); the SGE Calculator shows the areas that are in close proximity of transit, while 
also showing the location of disadvantaged communities (per SB 535). The disadvantaged communities overlay is key to being able to inform people of the need to enact planning processes with the members of the community, where they can determine how they want to manage these forces, and where they can choose to enact anti-displacement policies and practices.

\section{THE DATA OF THE SGE CALCULATOR}

The data and sources that show up on the calculator's dashboard on the right side of the screen are shown in the table below.

The SGE calculator shows two types of data: the first are urban quality outcome metrics that gauge the Sustainability, Livability, and Equity Performance of an area. For these cases lower values are better, such as lower VMT lower carbon emissions, etc.

Table 2. Data Used in the Smart Growth \& Social Equity Calculator

\begin{tabular}{cc}
\hline Metric & Data Source(s) \\
\hline Sustainability, Livability, Equity Performance \\
Lower Values are Better
\end{tabular}

Vehicle Miles Traveled per Household

Housing Affordability

Transportation Affordability

Pedestrian Collisions per 100,000

Pedestrians

Walkscore

Cardiovascular Disease

Obesity
From HUD's 2012 Housing Affordability Index Data Set (HAI) - hh_type1_vmt- Vehicle Miles Traveled per Household (the authors are working to get updated VMT per capita data from Caltrans)

HUD's 2012 Housing Affordability Index Data Set (HAI) (the authors use this measure as it is aggregated to Census Block Group level)

hh_type1_: housing cost as a percent of income for the regional typical household, defined as Avg $\mathrm{HH}$ size for region, median income for region, average number of commuters per $\mathrm{HH}$ for region

From HUD's 2012 Housing Affordability Index Data - hh_type1_t

Transportation Injury Mapping System (TIMS) 2010

Pedestrian collisions per 100,000 pedestrians

Frontseat

Centers for Disease Control: 500 Cities Data Cardiova_1

Centers for Disease Control: 500 Cities Data

OBESITY_Cr 
Second are urban form livability opportunity measures. These are measures of the built environment that provide people the ability to access livability opportunities-such as ability to access jobs via walking and transit.

\begin{tabular}{ll}
\hline & $\begin{array}{c}\text { Urban Form/Livability Opportunities } \\
\text { Higher Values are Better }\end{array}$ \\
\hline Transit Jobs Accessibility & EPA's Smart Locations Data Set (SLD) 2013 \\
& D5br: Jobs within 45-minute transit commute, distance \\
& decay (walk network travel time) weighted \\
Population Density (population/acre) & SLD \\
& D1b: Gross population density (people/acre) on \\
& unprotected land \\
Jobs Density (employees/acre) & SLD \\
& D1c: Gross employment density employees (jobs)/acre \\
& on unprotected land, 2013 \\
Pedestrian Environment (intersection density) & SLD \\
& D3bmm4: Intersection density in terms of multi-modal \\
& intersections having four or more legs per square mile \\
\hline
\end{tabular}

\section{WHY VMT IS THE FIRST THING SHOWN ON THE SMART GROWTH EQUITY CALCULATOR?}

Why is VMT per Household is the first layers that shows up when you open the SGE Calculator? VMT per household is used as this is one of the most important measures for key issues were dealing with, such as housing climate action planning and the new environmental regulations replacing LOS with VMT. Why start with VMT?

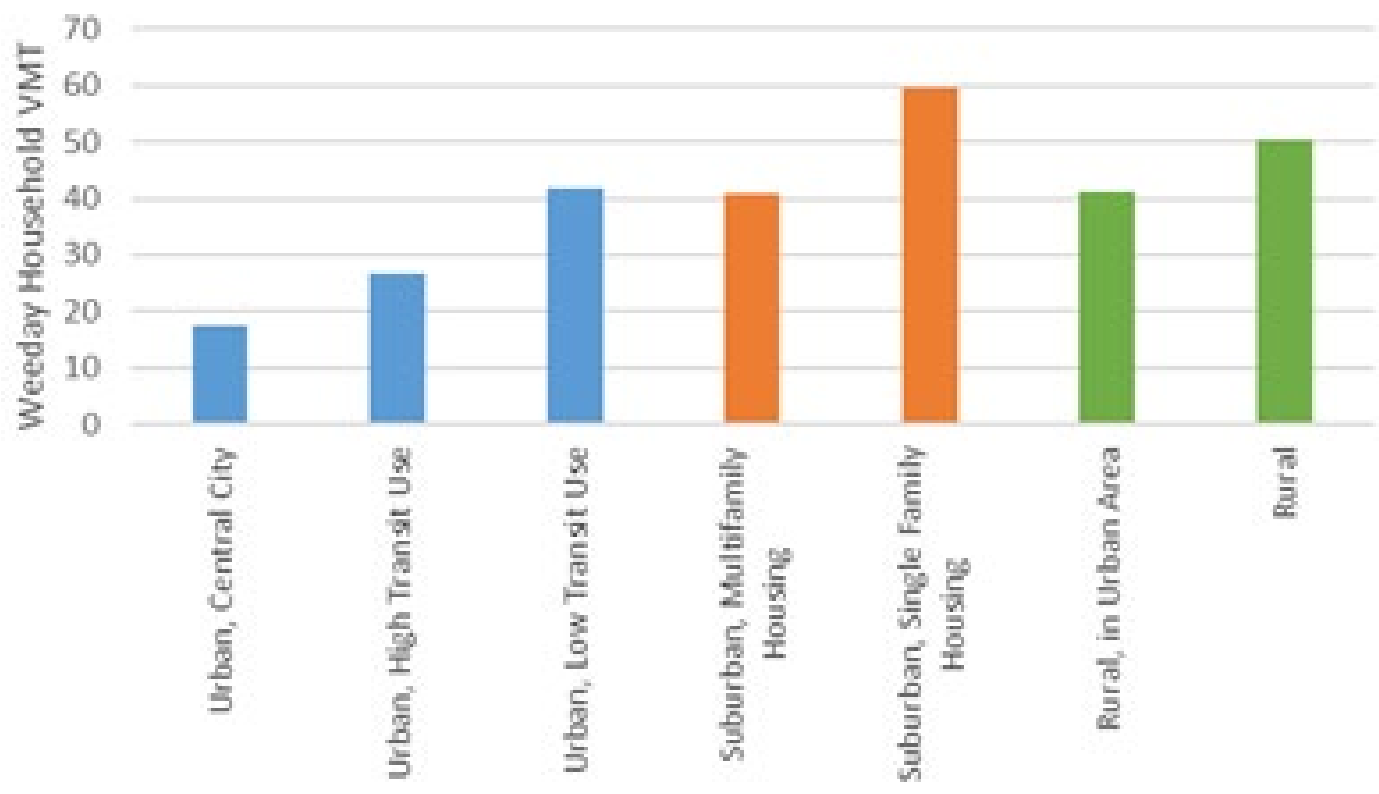

Figure 4. The Location Efficient/Neighborhood Design (LEND) Place Typology and VMT

Source: Adapted from Deborah Salon, "Quantifying the Effect of Local Government Actions on VMT", California Air Resources Board and California Environmental Protection Agency, Report 09-343, February 14, 2014 , pages 37-38. https://www.arb.ca.gov/research/apr/past/09-343.pdf 


\section{USING VMT TOWARD REGIONAL LAND USE PLANNING TO SUPPORT REGIONAL TRANSPORTATION PLANS}

The connection between VMT, urban areas, and transit use illustrates how a regional land use plan that can achieve a better balance between housing and jobs. By doing such things as encouraging infill development and curbing urban sprawl, a regional transportation plan can be improved by lowering overall trip distances and automobile travel and supporting transit, walking, and bicycling. Such Vehicle-Miles Traveled (VMT) reduction policies operate through regional land use planning and related planning pricing mechanisms, and they should be supported at all levels of government.

\section{THE USES OF THE SGE CALCULATOR}

In short, the SGE Calculator can be used in the following ways:

- Project development review analysis under SB 743, which allows for environmental streamlining of significant developments in areas that are $15 \%$ below regional averages for VMT.

- Climate action planning: Shows how many pounds of carbon per household will be generated from travel in different location in the region.

- New housing initiatives: This tool can help ensure new housing initiatives are equitable: first, it shows the areas that are in close proximity of transit, while also showing the location of disadvantaged communities, per SB 535, which is key to then being able to inform people to enact anti-displacement policies and practices.

- Better transportation and land use coordination between regional transportation planning agencies and local land use authorities, by providing key transportation and land use information at both regional and local scales.

- Helps inform NIMBY conversations by giving people access to key data, such as VMT and pounds of carbon per household in order for all parties to better understand why development should occur in transit/bike/walk accessible areas; by giving people a regional perspective and helping them see how everything is connected and needs to be coordinated through both land use and transportation, everyone can get on the same page.

- Performance evaluation of future scenarios related to Autonomous Vehicles (AVs) and Mobility as a Service (MaaS).

- The SGE Calculator also provides an Atlas of all train stations in California rating them according to their performance as described in the Smart Growth \& Transportation/ Land Use Integration (TLI) performance typology outlined in the Paper Are All Stations Equal and Equitable? (Appleyard et al. 2019). For more information, see below. 


\section{TOD ATLAS: THE EQUITY OF URBAN QUALITY AROUND TRAIN STATIONS}

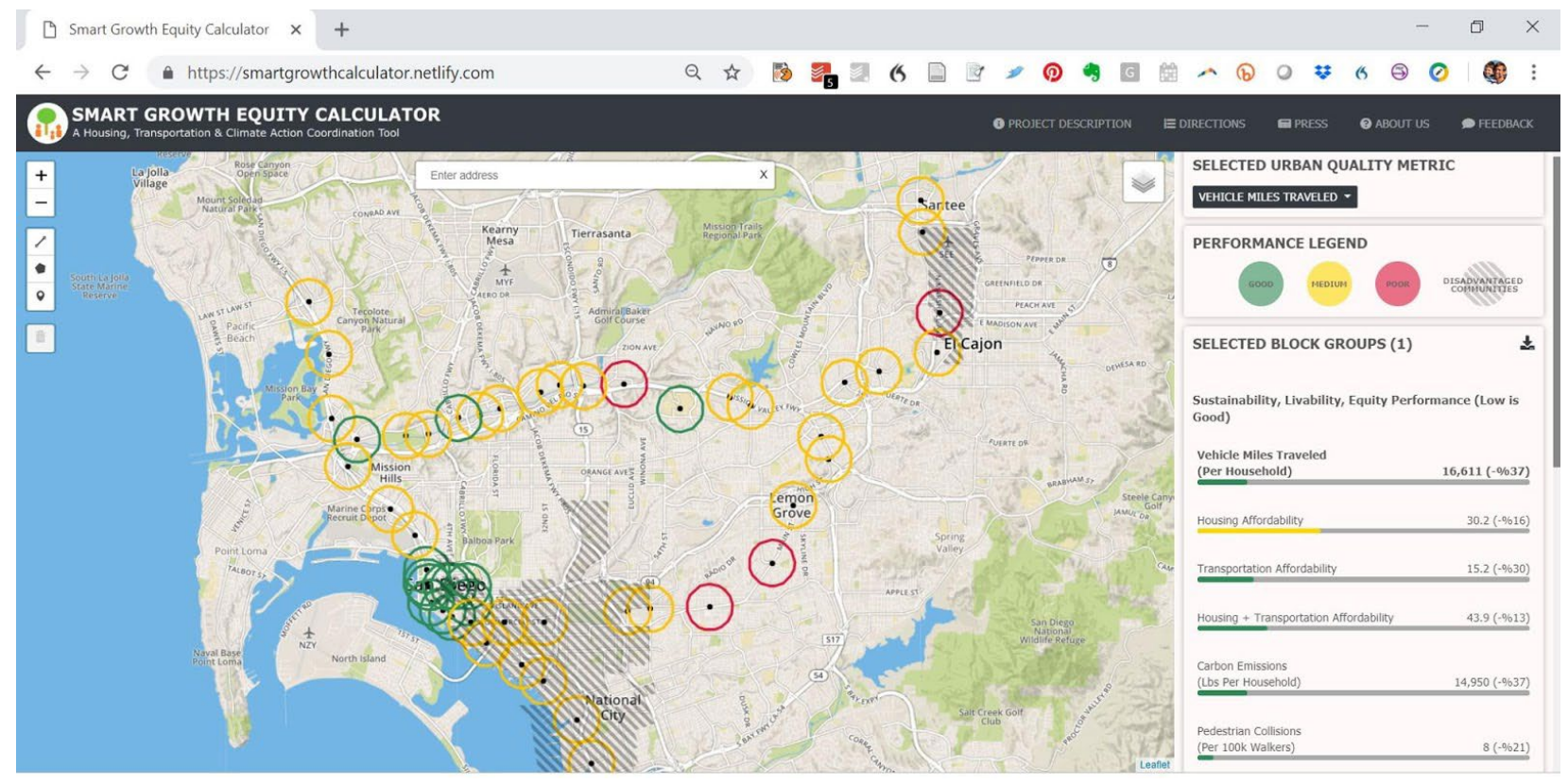

Figure 5. Light Rail Station performance and 1/4-mile overlay in the Smart Growth Calculator

In the SGE Calculator all the light rail stations are colored coded according to their performance as described in the Smart Growth \& Transportation/Land Use Integration (TLI) performance typology outlined in the Paper Are All Stations Equal and Equitable? (Appleyard et al. 2019): Red = Emerging; Yellow = Transitioning; Green = Integrating. The indicators on the right show the performance of a sample integrating station: this scenario features lower regional averages for household Vehicle Miles Traveled, Carbon Emissions, and Transportation Expenditures, but challenged in terms of affordability because of paradoxically higher housing costs. The hatched areas on the map locate Californiadesignated disadvantaged communities deserving protection from forces of displacement via targeted policies. For more information, see https://smartgrowthcalculator.netlify.com/ or http://bit.ly/SmartGrowthEquity (Appleyard et al., 2018). 


\section{THE SMART GROWTH EQUITY (SGE) CALCULATOR USER GUIDE}

The following is the narrative of the "Directions on Using the SGE Calculator".

These steps are also demonstrated in a YouTube video, found here: https://youtu.be/ vD2koMvKL8M. Below is the narrative.

Welcome to the beta version of our Smart Growth Equity Calculator! This Calculator is designed to help people, public agencies, and professionals make better decisions about growth and development (where and what kind) by allowing them to explore and understand urban quality throughout a community and a region, and how this urban quality relates to sustainability, livability, and social equity. We have detailed instructions below, but for a quick overview of the calculator's capabilities, see the following video:

\section{Viewing Urban Quality Metrics}

When you open the Calculator, the first layer that comes up shows Vehicle Miles Traveled per household, which is an important metric for climate action planning, as well as evaluating environmental impacts of development projects. The lighter areas in this VMT layer shows low VMT per household, whereas the darker red areas indicate of higher VMT. Using mouse, exploring the region and these urban quality metrics is made easy through the dynamic hover select capability of your mouse. As you move through the region, these indicators will change based on your selections:

\section{Legend [-]}

High Performing Transit Station Areas Medium Performing Transit Station Areas Low Performing Transit Station Areas

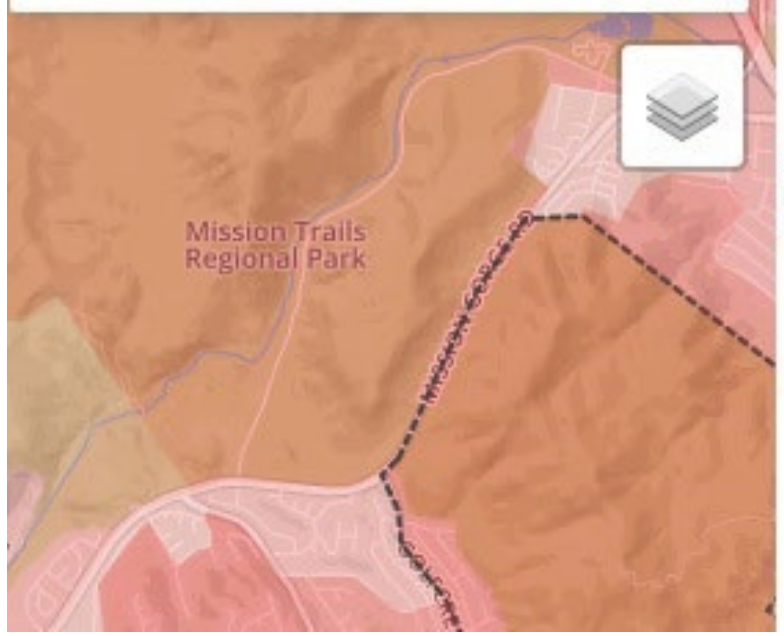

\section{Block Groups Selected}

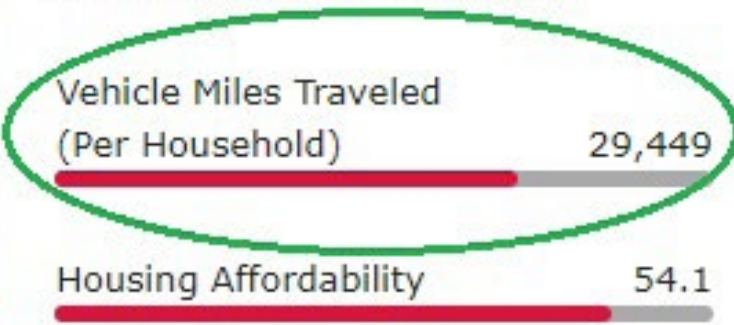

Transportation

Affordability

24.5

Figure 6. Urban Quality Metrics Column Showing VMT 
In addition to VMT, we have included a number of other urban quality metrics related to environmental impacts, affordability, health, and social equity. These other layers can be viewed by selected the "Select Urban Quality Metric" dropdown on the right-hand side:

\section{Legend [-]}

High Performing Transit Station Areas Medium Performing Transit Station Areas

Low Performing Transit Station Areas

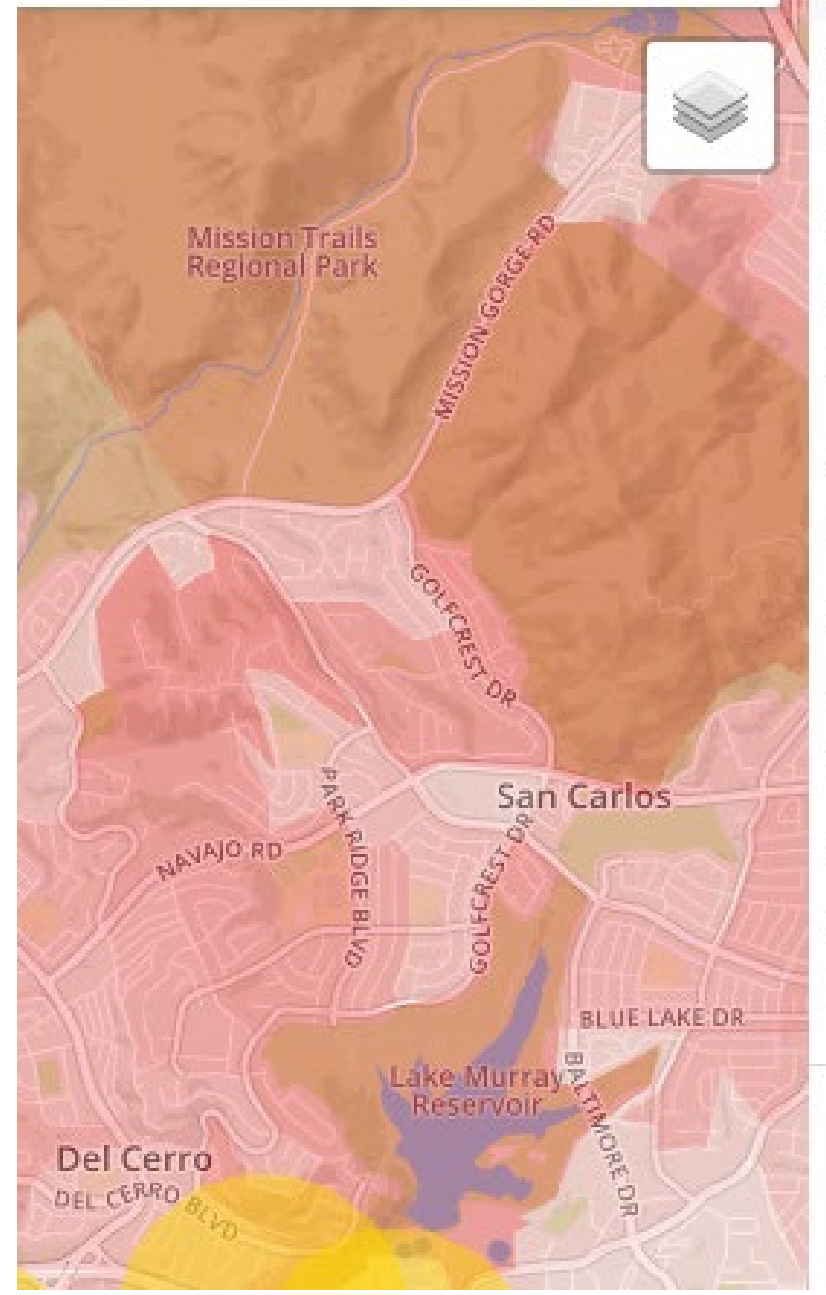

\section{Select Urban Quality Metric:}

\section{VEHICLE MILES TRAVELE:) -}

Vehicle Miles Traveled

Housing Affordability

Transportation Affordability

Housing + Transportation Affordability

Dwelling Density

Carbon Emissions

Pedestrian Collisions

Population Density

Jobs Density

Jobs Accessibility

Walkability

WalkScore

Walking Percent

Cardiovascular Disease

Obesity

Carbon Emissions

(Lbs Per Household)

N/A

\section{Figure 7. Selecting Different Urban Quality Metrics}

The circles show half mile catchment areas around transit stations using the high (green), medium (yellow), low (red) smart growth performance typology, based on our national study of urban quality of the National Academies of Sciences. 


\section{Legend [-]}

High Performing Transit Station Areas

Medium Performing Transit Station Areas

Low Performing Transit Station Areas

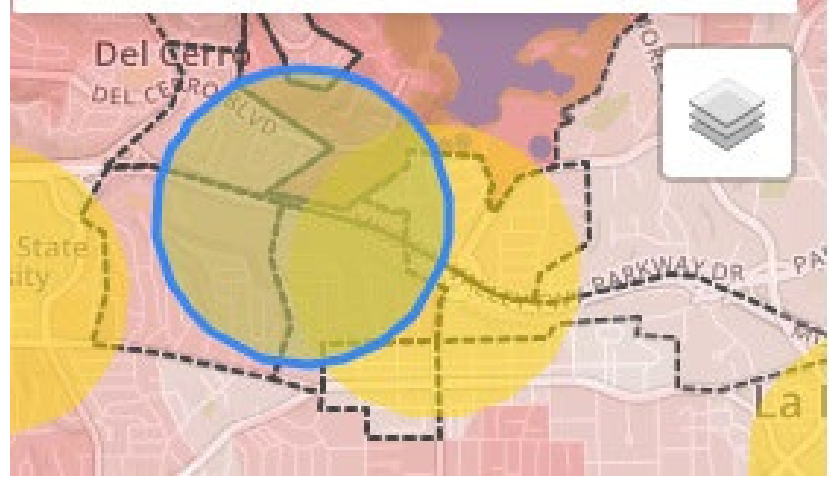

Select Urban Quality Metric:

VEHICLE MILES TRAVELED

8 Block Groups Selected

Vehicle Miles Traveled

(Per Household)

23,254

Housing Affordability

39.1

Figure 8. Selecting Areas in the Smart Growth Calculator

\section{Selecting Layers}

The Smart Growth Livability Calculator allows users to turn overlays on and off by using the layer selection control, which is located in the top-right corner of the map:

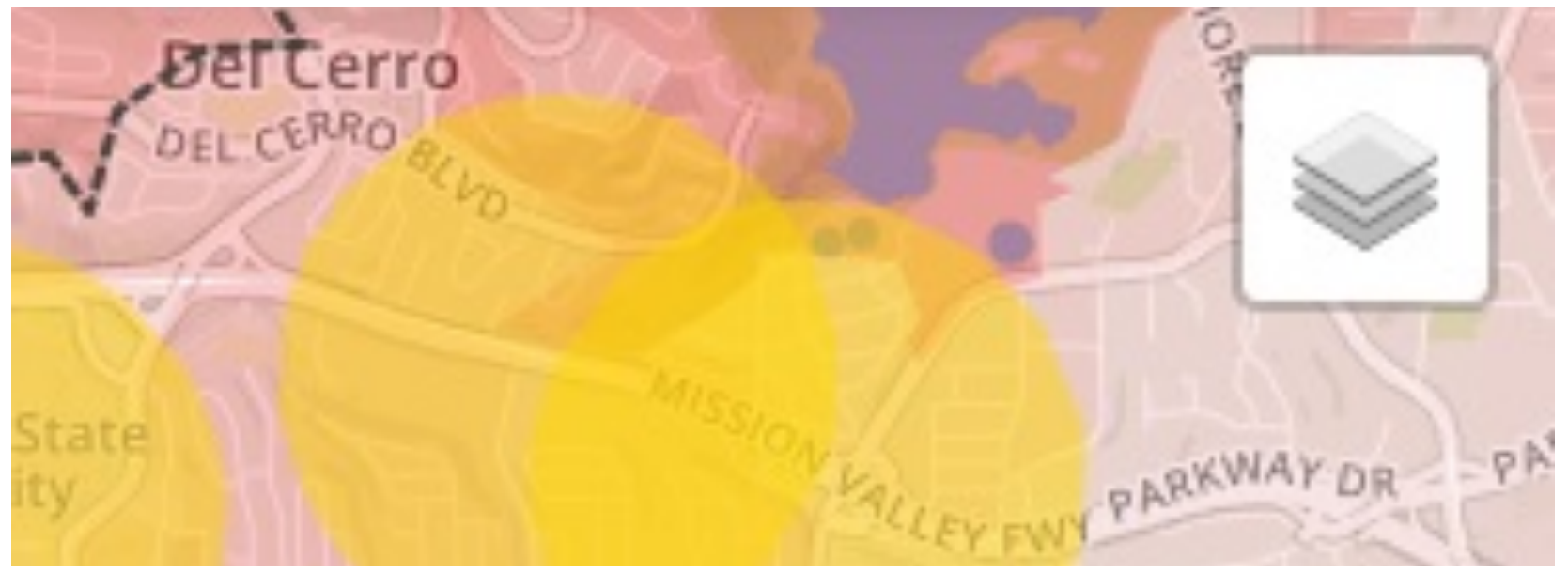

Figure 9. Locating Layer Selection

Hovering over the layer selection control will display the layers that are loaded into the calculator. show or hide layers by selecting or deselecting the checkboxes next to each layer label: 


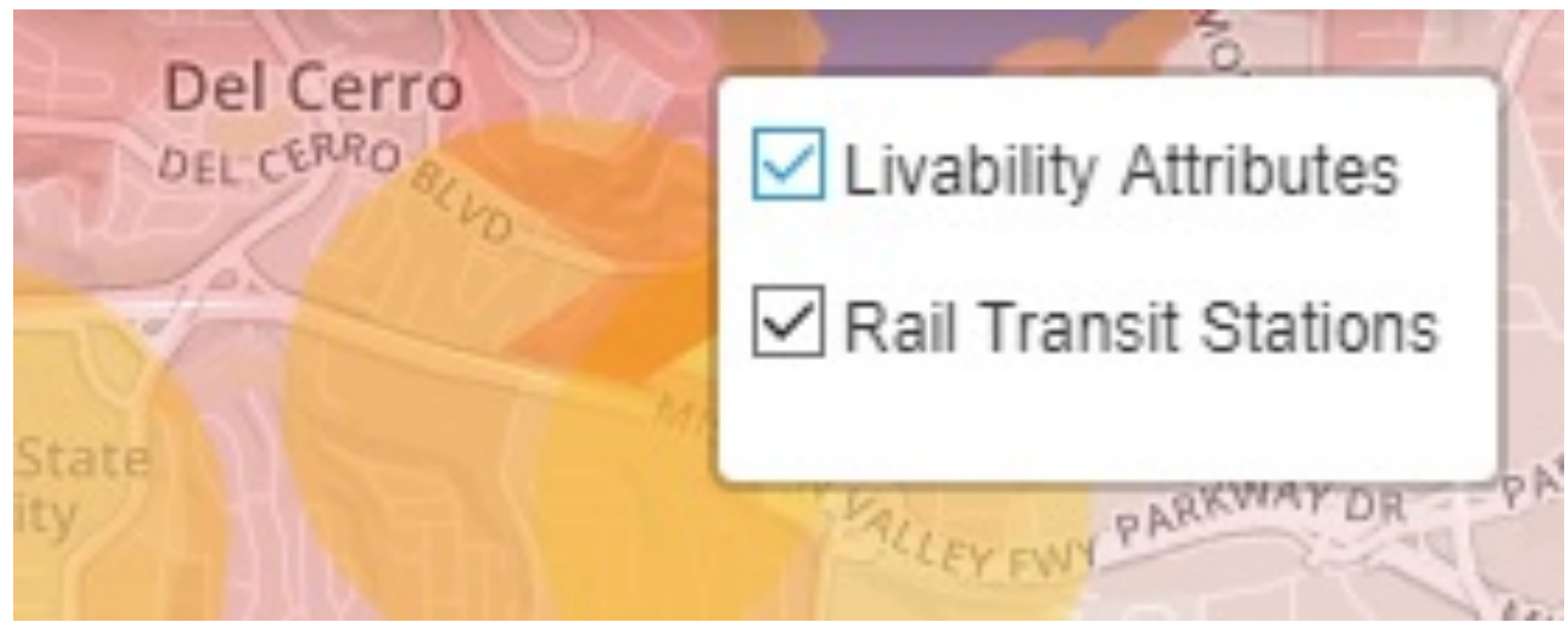

Figure 10. Toggle Layers 


\section{THE SGE CALCULATOR IN ACTION: ILLUSTRATIVE EXAMPLES}

\section{NEW ENVIRONMENTAL REGULATIONS FOR PROJECT DEVELOPMENT REVIEW: USING VMT INSTEAD OF LEVEL OF SERVICE}

Senate Bill 743-which allows for environmentally streamlining of significant developments in areas that are $15 \%$ below regional averages for Vehicle Miles Travelled (VMT)—could be a significant game changer in California's ability to achieve a more sustainable, livable, and equitable future.

Why should VMT be below 15 percent of regional averages?

- According to the California Office of Planning Research, $15 \%$ is chosen for the following reasons:

- Caltrans Strategic Plan: Reduce VMT/cap $15 \%$ by 2020

- SB 375 targets $\approx 15 \%$ collectively statewide

- $\mathrm{AB} 32$ scoping plan recommends local governments set GHG

- Reduction targets at $15 \%$ below existing by 2020

- Research shows $15 \%$ VMT mitigation is generally achievable

- (See CAPCOA's Quantifying Greenhouse Gas Mitigation Measures)

\section{How Using VMT Instead of Level of Service Help Transform our Auto- Mobility Paradigm? An Illustrative Example}

The pictures in the image below illustrate a critical problem with using level of service (LOS), especially if the goal is to achieve more sustainable, livable and equitable outcomes. The top image shows an open road that a congestion. Under the old level of service paradigm, this over the congested road would receive the highest grade, A. The problem is that this type of street is more likely located in a suburban or exurban area with a low density, and perhaps more importantly, lower levels of regional centrality and access to jobs. Using the SGE Calculator, it can be seen that such an area could have relatively high levels of VMT per household-somewhere in the range of 25-28,000 vehicle miles a year. Using the SGE Calculator, it can also be seen that this area has a VMT per household figure of $8-10 \%$ above the regional average, as shown on the right side of the dashboard display for VMT per Household. 


\section{Housing \& Transportation Game Changer}

\section{California's SB 743: New Measures for Development Review \& CEQA Streamlining} Use Vehicle Miles Traveled (VMT) instead of congestion-Level of Service (LOS)

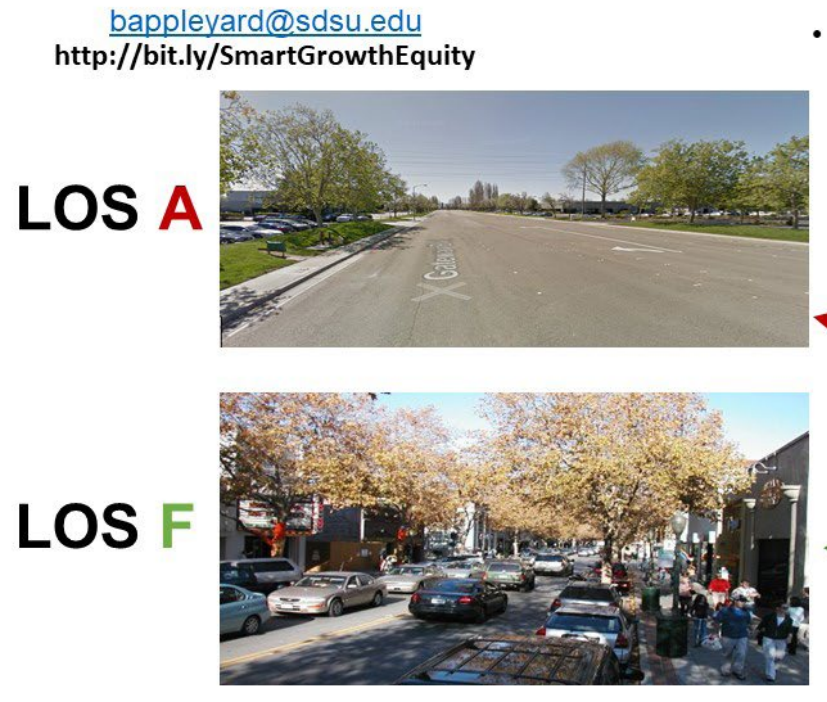

- Key Calculator Task:

- ID Areas with VMT $15 \%$ below (or lower) the City/Regional = CEQA Streamlining (Green is lower/better)

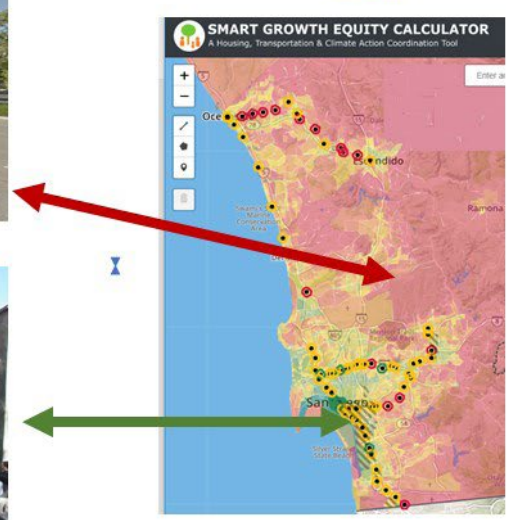

http://bit.ly/SmartGrowthEquity https://smartgrowthcalculator.netlify.com/

Figure 11. SB 743 Visualization and Examples in Smart Growth Calculator

\section{How Can the SGE Calculator Help with VMT Environmental Quality Analysis?}

The SGE helps by allowing measurement of the VMT per household for one's area of interest in relation to agreed-upon regional average. In the example below, the selected areawhich is the College Area Community just to the south of San Diego State University-is compared against the average VMT per Household for the entire county of San Diego.

Remember, to select an area, use the corner selection tool on the left-hand side of the screen. (If selecting another area is desirable, be sure to deselect the initial area by selecting the trash can icon at the bottom of the toolbox.)

The SGE Calculator then averages the urban quality metrics across the selected area and then compares it to the regional average. In the example below, the area of interest is cumulatively at about $15 \%$ below the regional average.

While more specific analysis is likely needed, this area shows promise for achieving the target of $15 \%$ below the regional average. Under the new California Environmental Quality Act Guidelines, per the new regulations of SB 743, this means that significant projects in this area may qualify for development review streamlining. Conversely, it shows how certain areas may be well above the regional average for VMT, and should no longer receive the benefits of development review streamlining that these areas used to receive under the old level of service (LOS) paradigm (favoring areas that were low-density, regionally inaccessible, and consequently more auto-dependent). 


\section{SMART GROWTH EQUITY CALCULATOR in Action}

College Area Community Plan by SDSU Urban Design Studio

( Green = areas of low Household Vehicle Miles Travelled VMT)

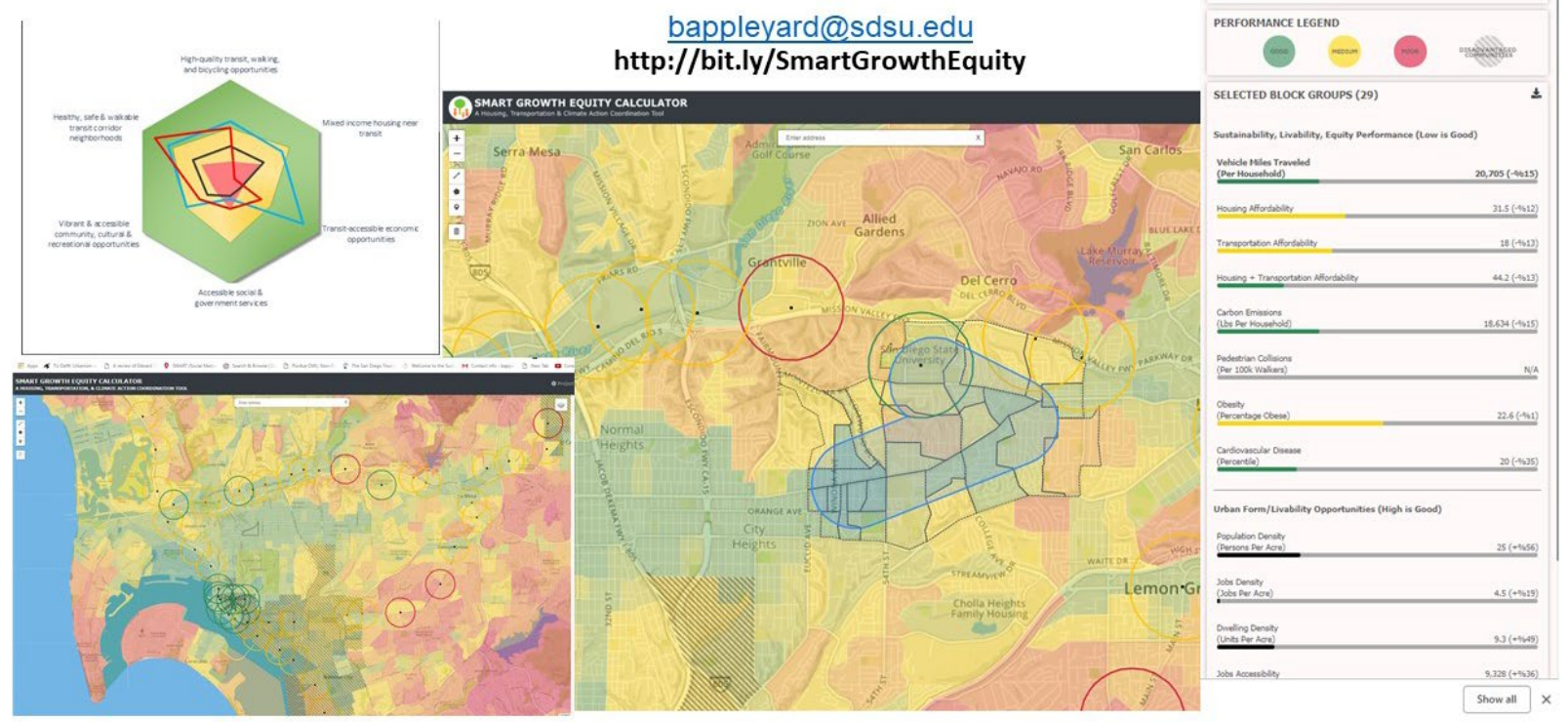

Figure 12. Smart Growth Calculator Used in San Diego College Area Community Plan

\section{CLIMATE ACTION PLANNING CASE STUDY}

The Carbon Emissions metric shows how many pounds of carbon per household will be generated from travel in different locations in the region.

\section{SMART GROWTH EQUITY CALCULATOR in Action}

Climate Action Planning

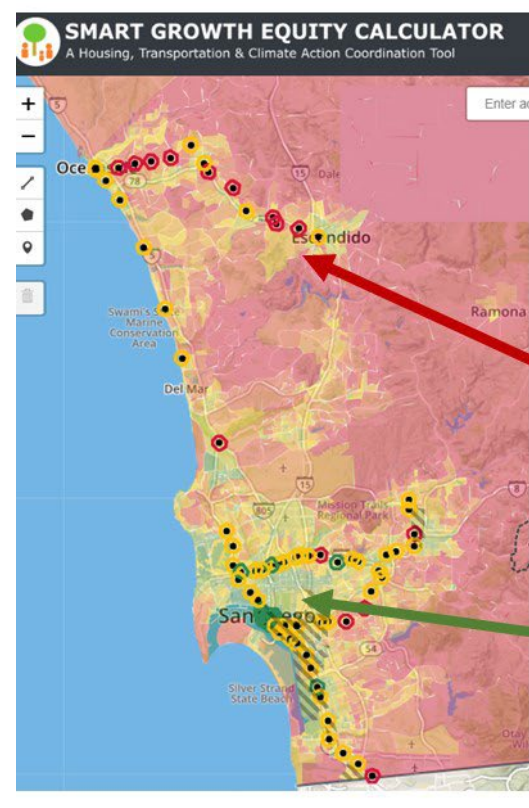

\author{
bappleyard@sdsu.edu \\ http://bit.ly/SmartGrowthEquity
}

New suburban housing developments

fast-tracked for approval by San Diego County
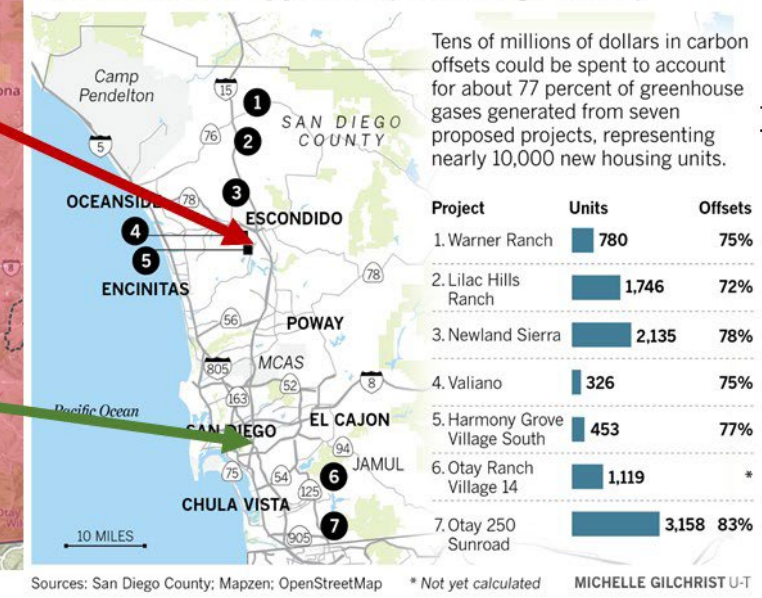

Tens of millions of dollars in carbon

for about 77 percent of greenhouse

gases generated from seven

proposed projects, representing

nearly 10,000 new housing units.

sets

$\%$

$\%$

*

$83 \%$
10,000 Households

$=$

$\underline{100,041,803}$

Extra pounds of carbon per year

vs.

Building In More

$\underline{\text { Transit Accessible Areas }}$

The

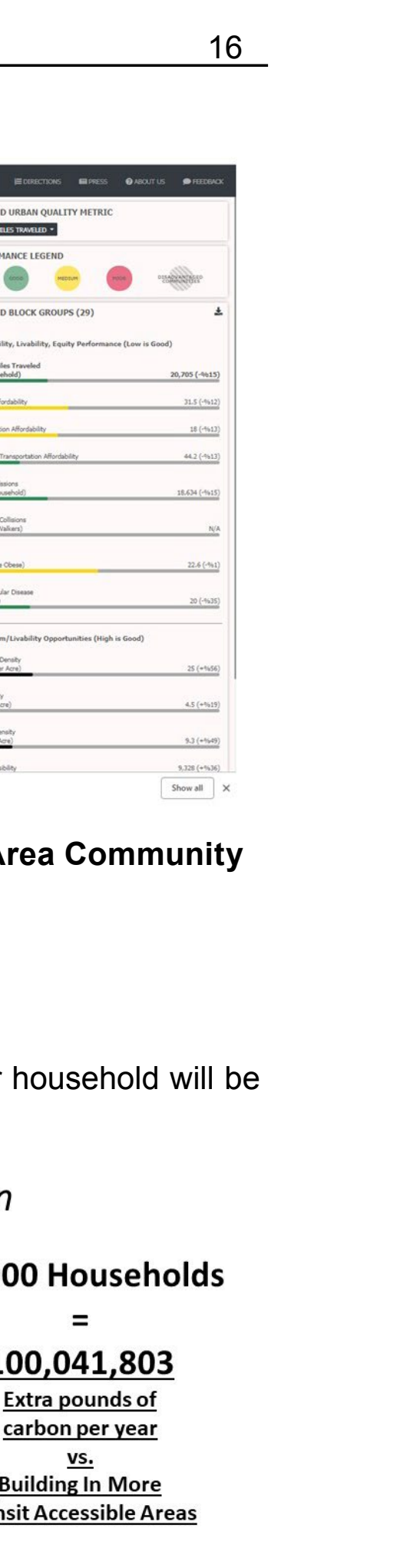


The SGE calculator can also help with Climate Action Planning. One way is by helping make better housing and jobs access location decisions by showing how many pounds of carbon per household will be generated from travel originating from different locations in a region.

In the spring of 2018, Nicole Capretz of the Climate Action Campaign called the author with a special request. She was trying to inform decisions to be made by the San Diego County Board of Supervisors regarding the fast-track approval of 10,000 housing units in suburban and ex-urban locations through the use of carbon offset credits.

Using the SGE Calculator functions and data, the authors were able to calculate the overall carbon footprint of these 10,000 units and then compare them to a more transit-accessible part of the region. For this, the research team used the somewhat suburban and highly auto accessible Linda Vista Trolley Station area, where households emit an average of 18,159 pounds of carbon a year-the lowest the authors have seen is about 15,000-so this is modest average for a transit-accessible area. The results are shown in the table below. 
Table 3. Carbon Emissions for select neighborhoods and housing developments

\begin{tabular}{|c|c|c|c|c|}
\hline & $\begin{array}{c}\text { Avg. Pounds } \\
\text { of Transport } \\
\text { Carbon } \\
\text { Emitted per } \\
\text { Household } \\
\text { (per Year) }\end{array}$ & Proposed Number of Units & & $\begin{array}{l}\text { Estimated } \\
\text { Pounds } \\
\text { of Carbon } \\
\text { Emitted }\end{array}$ \\
\hline $\begin{array}{l}\text { Warner } \\
\text { Ranch }\end{array}$ & 28,479 & 780 & & $22,213,620$ \\
\hline Lilac Hills & 28,224 & 1,746 & $49,279,104$ & \\
\hline $\begin{array}{l}\text { Newland } \\
\text { Sierra }\end{array}$ & 27,987 & 2,135 & & $59,752,245$ \\
\hline Valiano & 27,475 & 326 & $8,956,850$ & \\
\hline $\begin{array}{l}\text { Harmony } \\
\text { Grove } \\
\text { Village } \\
\text { South }\end{array}$ & 27,475 & 453 & & $12,446,175$ \\
\hline $\begin{array}{l}\text { Otay Ranch } \\
\text { Village } 14\end{array}$ & 28,956 & 1,119 & $32,401,764$ & \\
\hline $\begin{array}{l}\text { Otay } 250 \\
\text { Sun Road }\end{array}$ & 28,956 & 3,158 & & $91,443,048$ \\
\hline $\begin{array}{l}\text { Total } \\
\text { housing } \\
\text { units }\end{array}$ & & 9,717 & & \\
\hline $\begin{array}{l}\text { Total pounds } \\
\text { of carbon for } \\
\text { county }\end{array}$ & & 9,717 & & $276,492,806$ \\
\hline $\begin{array}{l}\text { Infill areas: } \\
\text { Linda Vista } \\
\text { Trolley } \\
\text { Station } \\
\text { (proxy for } \\
\text { Mid-Coast } \\
\text { Trolley } \\
\text { Stations, } \\
\text { Golden Hill, } \\
\text { North Park) }\end{array}$ & 18,159 & & $176,451,003$ & \\
\hline $\begin{array}{l}\text { Total pounds } \\
\text { of carbon } \\
\text { saved in infill } \\
\text { areas }\end{array}$ & & & & $100,041,803$ \\
\hline
\end{tabular}

When comparing the placement of these 10,000 units in auto-dependent parts the region, the households will generate more than 100 million pounds of carbon a year compared to if they were placed in a more transit accessible part of the region.

\section{SUPPORTING SUSTAINABLE AND EQUITABLE HOUSING PLANS}

The SGE Calculator can help with the development of more sustainable and equitable housing plans in the following ways:

- Ensure new housing initiatives to automatically up-zone near transit and job-rich areas (e.g. SB 50) are conducted through an equity lens. 
- Help inform NIMBY opposition

- Lead to better transportation and land use coordination

Ensure new housing initiatives to automatically up-zone near transit and job-rich areas (e.g. SB 50) are conducted through an equity lens.

This SGE Calculator can help ensure new housing initiatives are equitable, by first showing the areas that are in close proximity of transit, while also showing the location of disadvantaged communities, per SB 535 (as shown with hatching). Knowing the location of these transit-rich areas and disadvantaged communities can help trigger the enaction of planning processes with the community members, which can help people enact antidisplacement policies and practices, if needed.

The SGE Calculator can also make sure that development pressures will be applied to the region by helping better inform NIMBY conversations around development, which can create further problems with regional equity if rich and powerful neighborhoods are able to fight development thereby putting inequitable pressure on poorer, less powerful neighborhoods to accept the development-poor people are displaced into areas where there is automobile dependence, and this could lead to serious equity issues related to access.

\section{How the SGE Calculator Can Help Inform NIMBY Conversations and Dialogues}

By giving people access to key data, such as location of areas that are more transit/bike/ walk accessible and have lower rates of VMT and pounds of carbon per household, then all parties can better understand and support why development should occur in these locations-the areas where, arguably, people have a better chance of freeing themselves from having to drive.

The SGE calculator was used in a particular case that can demonstrate its effectiveness. On September 19, 2018, the Voice of San Diego featured the SGE calculator article titled, City Is Poised to Back Down on Plan to Increase Height Limit - Again. To show how planning support tools like the Smart Growth Equity Calculator can help inform NIMBY Conversations and Dialogues, please see the following relevant portion of the article:

"Failing to build as many homes as possible along the Morena Boulevard corridor is a missed opportunity for the entire region," said Bruce Appleyard, a professor of urban planning at SDSU.

"Allowing people to live here, as opposed to other parts of the region, you have the greatest chance of getting people to drive less, and to switch to using transit or biking more," he said. "From a global, regional and local perspective, following a \$2 billion transit investment, we need to make these areas accessible for more people."

Appleyard has developed what he calls a Smart Growth Calculator-it uses data from the Environmental Protection Agency and the Housing and Urban Development Department 
to determine the average pounds of carbon emissions per household within specific areas.

Households near the existing trolley station in Linda Vista-near multiple employment centers and regional destinations, and with a temperate coastal climate-emit an average of 10,000 fewer pounds of carbon per year than households built in undeveloped portions of San Diego County, according to Appleyard's analysis.

"That means that 10,000 urban fringe units will emit about 100 million more pounds of carbon a year than if they were allowed to be built in transit-accessible locations like the Morena corridor," Appleyard wrote in an email.

Even just moving from a community like Bay Park that doesn't have high-frequency transit access to one that does (like when the Mid-Coast begins service) reduces the average carbon emissions per household by 6,000 pounds per year.

But there's a fundamental equity issue the city must confront too, he argued. When development is restricted from areas like Bay Park, it increases development pressure on lower-income or minority communities that have less political power to push back.

"People along the Mid-Coast corridor need to understand and appreciate that," Appleyard said. "If they are able to build on their access to power to restrict accessibility to their neighborhood, they'll put more pressure on these communities that have been disadvantaged for decades."

Around the same time, the SGE Calculator was featured in a KPBS news story, which can be found at https://ytcropper.com/cropped/-z5ba4840ae9494.

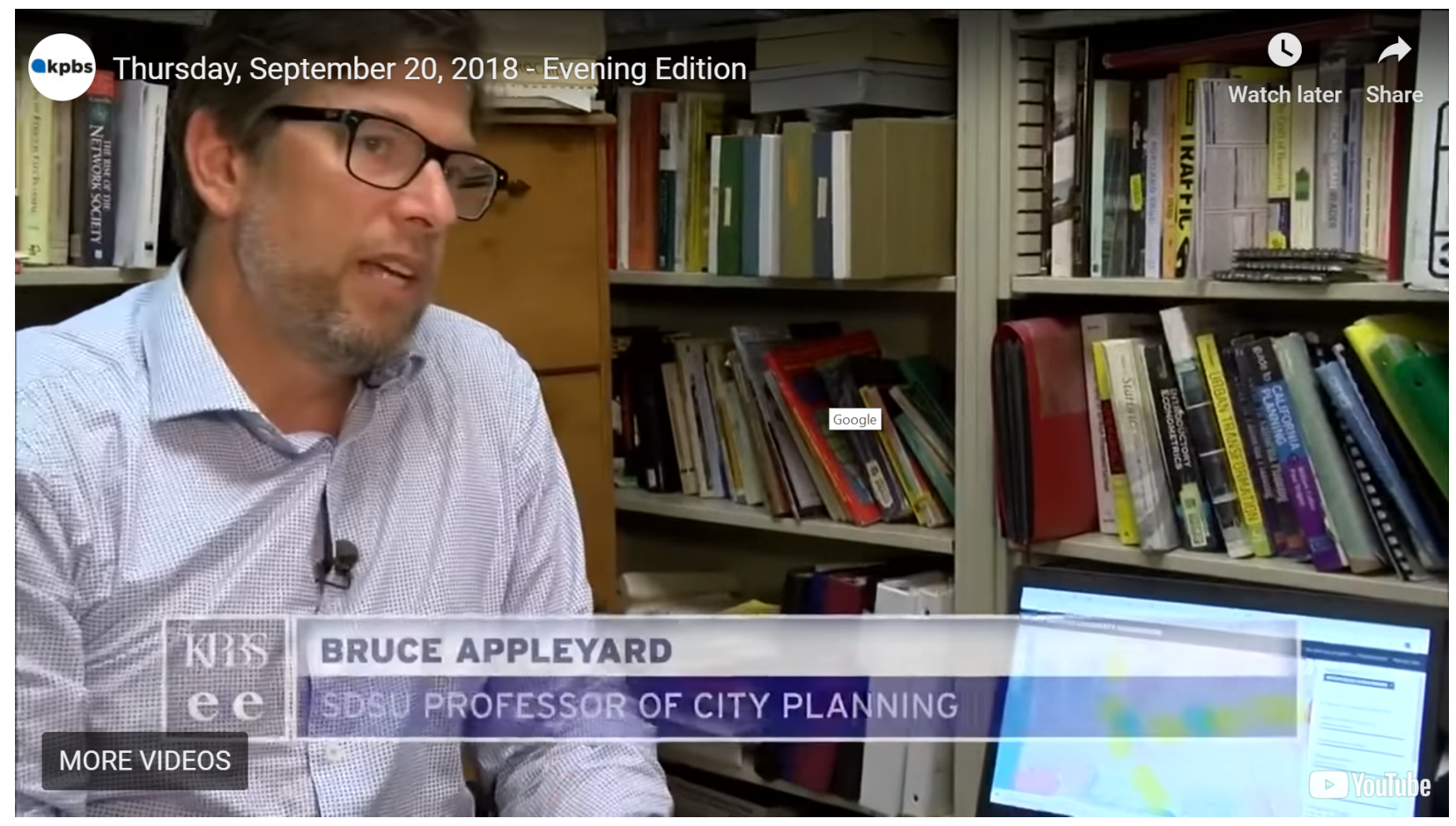

Figure 14. Dr. Appleyard Featured on KPBS San Diego 
Essentially, by giving people a more comprehensive regional perspective we can help them see how everything is connected and needs to be coordinated through a comprehensive land use and transportation approach. Better transportation and land use coordination between regional transportation planning agencies and local land use authorities, by providing key transportation and land use coordination information at both regional and local scales, will help our region's and communities achieve a more comprehensive set of sustainability, livability, and equity outcomes.

\section{SG/L and SGE Calculators at Work in the Studio and Classroom: College Area Community Planning and Urban Design Studio}

\section{SMART GROWTH EQUITY CALCULATOR in Action}

College Area Community Plan by SDSU Urban Design Studio

(Green = areas of low Household Vehicle Miles Travelled VMT)
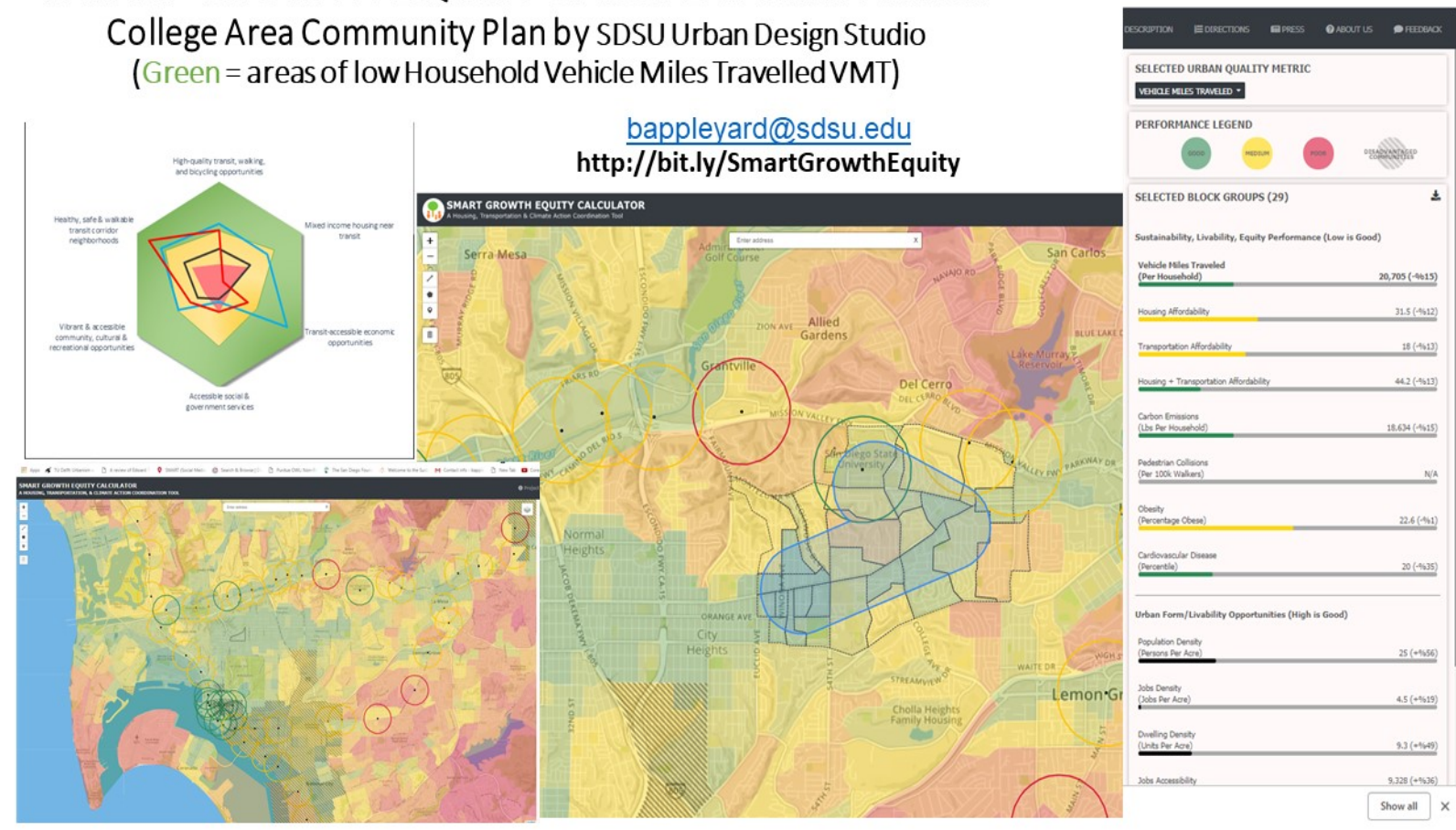

\section{Figure 15. Smart Growth Calculator Used for Community Planning (San Diego College Area Community Plan)}

The Smart Growth Equity and Smart Growth Livability Calculator were both put to work in SDSU's Spring 2019 Urban Design Studio (CP 700)-a course designed to help students learn graphic, verbal, and written communication skills. Specifically, this course is designed to help students understand how to analyze and communicate regarding existing conditions, opportunities \& constraints, and values \& goals. In Spring 2019, SDSU Studio students used the SGE and Livability Calculators to help conduct an analysis of existing conditions and then analyze the development of future scenarios with designs, plans, simulations, and assessments that help inform discussions around future actions and policies.

In Spring 2019, the SDSU Studio students used these tools to assist in the development of presentations and final reports, and then the creation of the update to the College Area Community Plan, in service of not only the College Area residents, but also other key 
stakeholders (City, SDSU, SANDAG, etc.) in developing and realizing future plans and designs for the area.

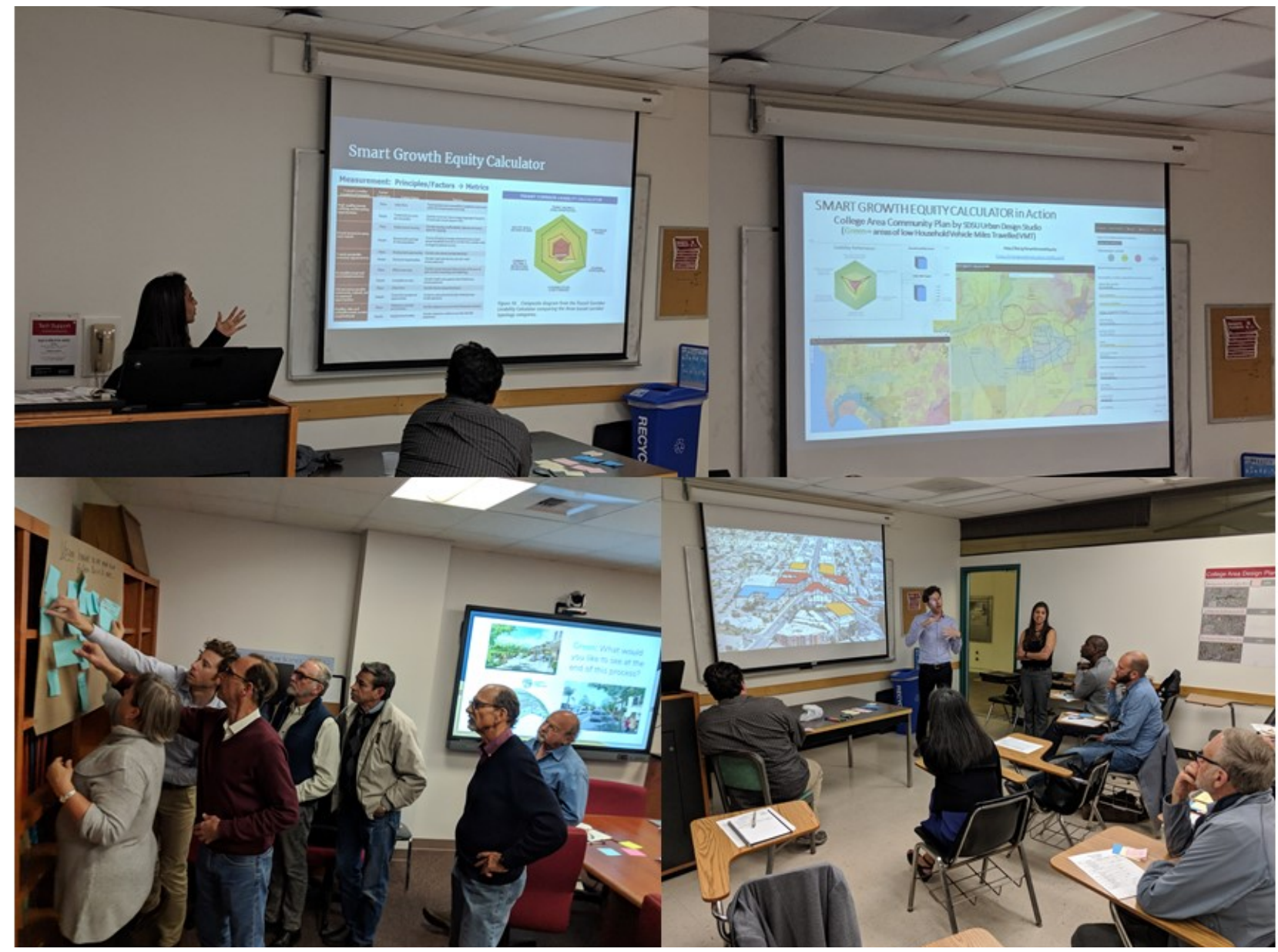

Figure 16. Students and Community Members Using the Smart Growth Calculator to Guide Discussion

\section{SGE AND SGE CALCULATORS IN RESEARCH}

Both the SG/L and SGE Calculators are also being used in research. In the upcoming publication by Dr. Appleyard and his student researchers, Alex Frost and Chris Allen, in the Journal of Transport and Health.

\section{Are All Transit Stations Equal and Equitable?}

This research finds that stations with higher levels of livability opportunity access to be significantly associated with key individual and societal quality of life outcomes such as lower rates of obesity, cardiovascular disease, and asthma. These higher performing stations also have higher rates of walking, bicycling, and transit ridership, and lower rates of driving, carbon emissions and pollution, household transportation cost burdens, and even unemployment rates. Unfortunately, they do not appear to be socio-economically inclusive and are significantly less affordable. 


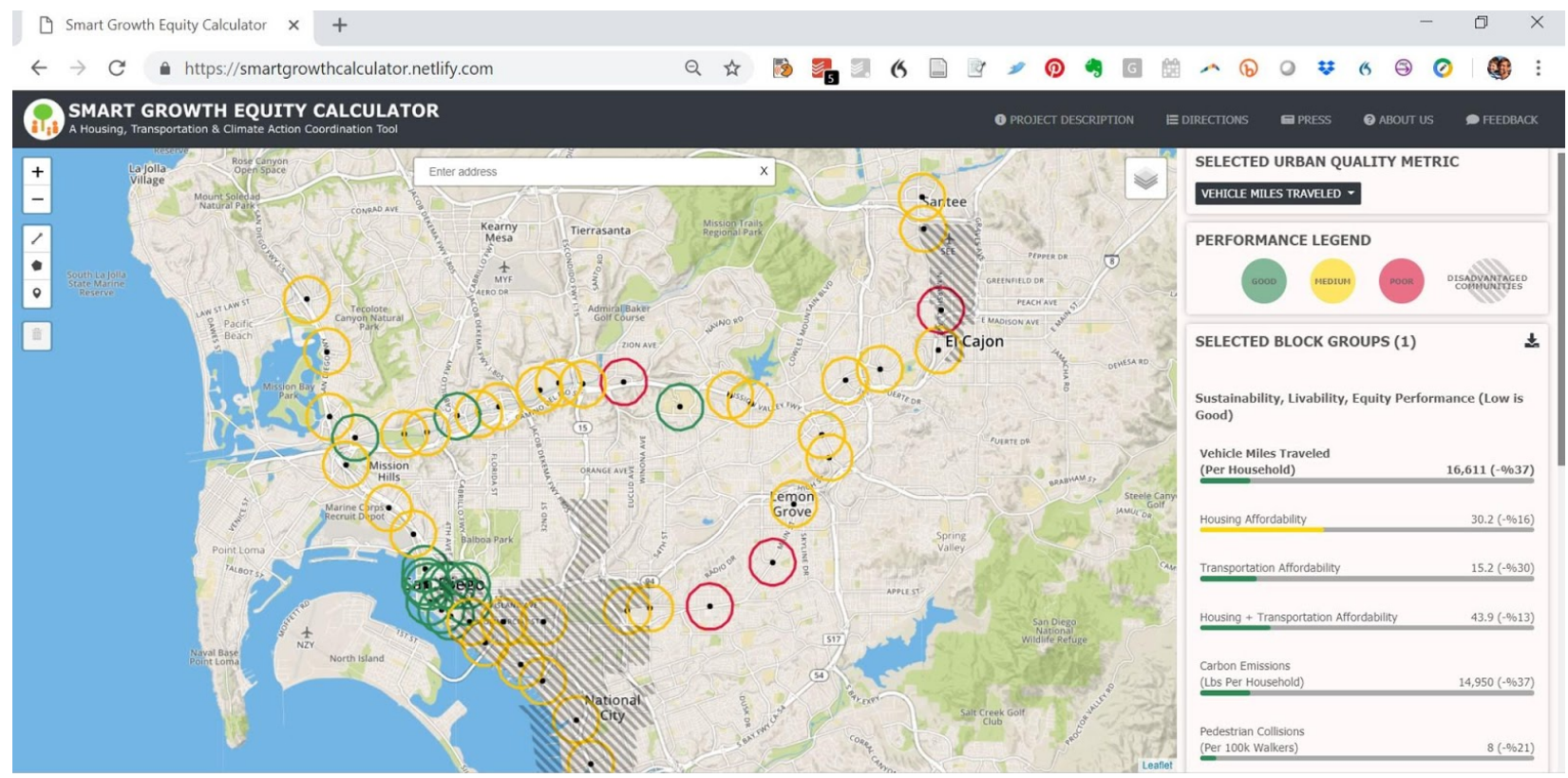

\section{Figure 17. Smart Growth Calculator with Transit and Disadvantaged Communities Overlay}

Figure above shows the performance of light rail stations in San Diego, California, as provided by the new online Smart Growth Equity Calculator, and according to the Smart Growth \& Transportation/Land Use Integration (TLI) performance typology outlined in this paper, where Red = Emerging; Yellow = Transitioning; Green = Integrating, which are the highest performing stations from an opportunity access perspective. The indicators on the right show the performance of a sample integrating station, with lower regional averages for household Vehicle Miles Traveled, Carbon Emissions, and Transportation Expenditures, but challenged in terms of affordability because of paradoxically higher housing costs. The hatched areas on the map locate California designated disadvantaged communities deserving protection from forces of displacement via targeted policies. For more information, see https://smartgrowthcalculator.netlify.com/ or http://bit.ly/SmartGrowthEquity (Appleyard et al. 2019). 


\section{A POTENTIAL APPLICATION FOR A FUTURE OF TRANSPORTATION INNOVATION, DISRUPTION, AND AUTOMATION}

\section{Illustrative Example:}

How different performance dimensions (efficiency versus effectiveness) evaluate (measure and understand) different transport and mobility services in different land use contexts (urban light rail versus suburban bus)

To illustrate how the SGE Calculator can be used to help inform a future of transportation innovation, disruption, and automation, the research team builds on previous work developing a new transportation-land use integration (TLI) performance measurement framework that-and this is critical-more clearly prioritizes the effective movement of people over the efficient movement of vehicles: see Appleyard \& Riggs (2017, 2018a, 2018b), and specifically the article "Measuring and Doing the Right Things".

For an overview, see figure 31 below, of the Transportation and Land-Use Coordination Performance Pyramid for Livability, Sustainability, and Equity-Prioritizing the Movement of People Through Holistic Approaches.

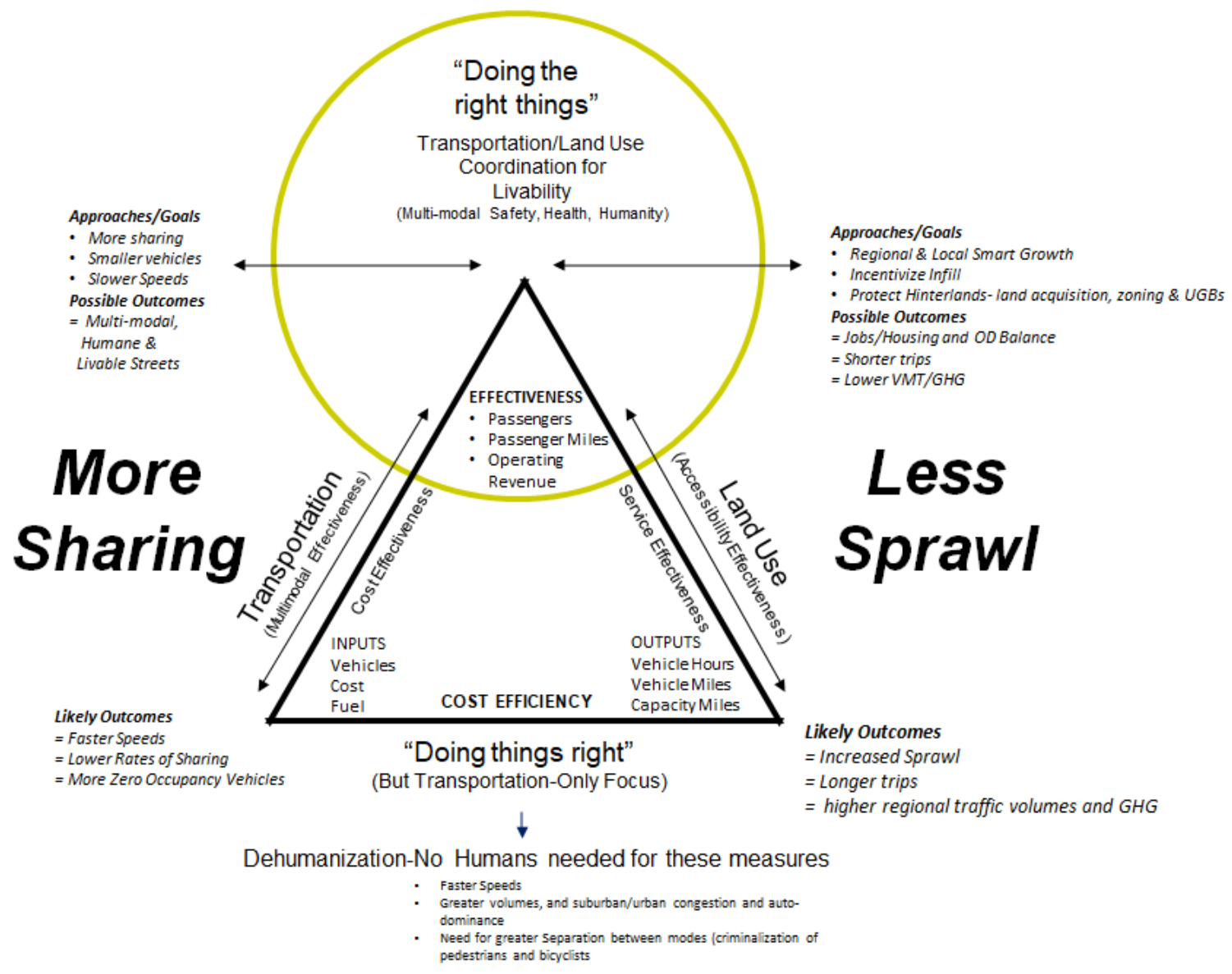

Figure 18. Transportation and Land Use Coordination Performance Pyramid for Livability, Sustainability, and Equity -Prioritizing 
This framework can be applied in a wide range of modeling and future scenario testing and back-casting situations. For scenario testing, as well as the identification and assessment of "refilling" versus "spilling" areas, one can also use tools and policy guides, like the Transportation Research Board's Livability Calculator and Handbook for Building Livable Transit Corridors (for more information, see http://www.trb.org/Main/Blurbs/174953.aspx).

To illustrate how this can be used to evaluate different autonomous or Mobility as a Service transport scenario, and, perhaps most importantly, different projected land use contexts, the researchers use conventionally available data for San Diego, California, that needs to be reported to the Federal Transit Administration, per Regulation 15. By demonstrating how different transport and mobility services perform in different land use contexts (urban light rail versus suburban bus) we can understand how this performance measurement framework could work in evaluating future transport scenarios, whether transit, ride-hailing, or autonomous vehicles.

For this illustration, see the map and table below which show a comparison of a suburban, bus transit system (red column and red area on map-showing areas of high household VMT), with an urban core transit system. In this case San Diego's Light Rail Transit (LRT) line is used and area it serves as a proxy, as shown in the green column and green areas on the map showing areas of relatively low household VMT. 


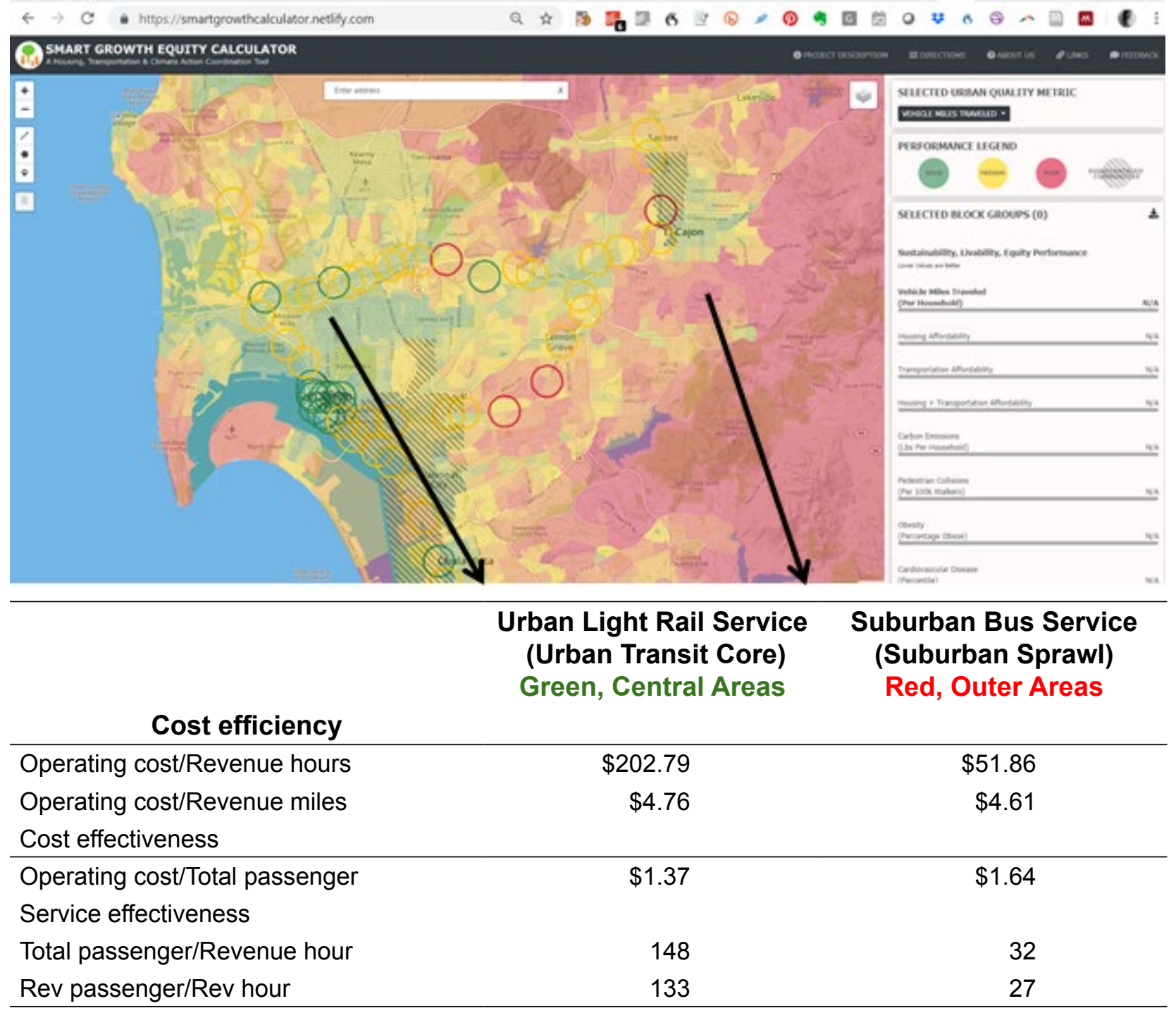

\section{Figure 19. Smart Growth Calculator Used to Compare Different Transit Systems}

From this example, the authors demonstrate how these performance evaluation dimensions comparing urban transit systems with suburban transit systems, in vastly different contexts, lead to very different indications of performance, prompting the research team to seek ways to re-calibrate this model (See Figure and Table below).

For example, a suburban bus transit system (red column and red area on map showing areas of high household VMT) could perform well regarding cost-efficiency (transit vehicle miles per operating cost and labor: $\$ 51$ for the suburban bus system, versus over $\$ 200$ for the urban LRT system), while actually carrying fewer passengers (number of passengers per vehicle hours of operation)-and performing poorly in terms of service effectiveness (Total Passenger/Revenue per Hour: 32 people served for the suburban bus system, versus over 140 for the urban LRT system).

As this example shows, we need to more clearly value urban, more walkable, transit accessible areas where there can be a more effective movement of people prioritized over the efficient movement of vehicles. While an urban LRT transit system can carry 
more passengers (service effectiveness), it might do so less efficiently because of slower speeds in more urban pedestrian- and bicycle-friendly (and livable) environments (Mekuria, Appleyard, and Nixon 2017). This illustrates the direct questions that should be asked: What kind of future is desired with MaaS and AVs? And, by extension, where is value placed in terms of how we measure, understand, and then enact policies to realize our visions for the future of our streets, communities, and regions? 


\section{NEW WAYS TO EXPLORE STREET DESIGNS}

The SGE Calculator also includes a link to https://www.restreet.com/. Building off of these principles we can begin to construct a framework for the street, developing design typologies and zones to design and better manage our streets. For example, it is possible to deconstruct an urban streetscape using tools like the Restreet.com participatory design tool, which is based on the open source tool StreetMix (Riggs, 2018a, 2018b, 2017)"publisher":"Social Science Research Network","publisher-place":"Rochester, NY","genre":"SSRN Scholarly Paper","source":"papers.ssrn.com","event-place":"Rochester, NY","abstract":"Emerging technologies are fundamentally changing how we plan, develop, and manage our cities. Given trends of increasing mobile use, local governments and public officials (and particularly city planners. As autonomous vehicles can capitalize on efficiencies in space utilization (side to side, and front to back), it might be possible to constrain right-of-way needs to create a more human-scale environments. This deconstruction is similar to the vision cast by Schlossberg, Riggs, Millard-Ball \& Shay (Schlossberg et al., 2018), in their white paper, Rethinking the Street in an Era of AVs.

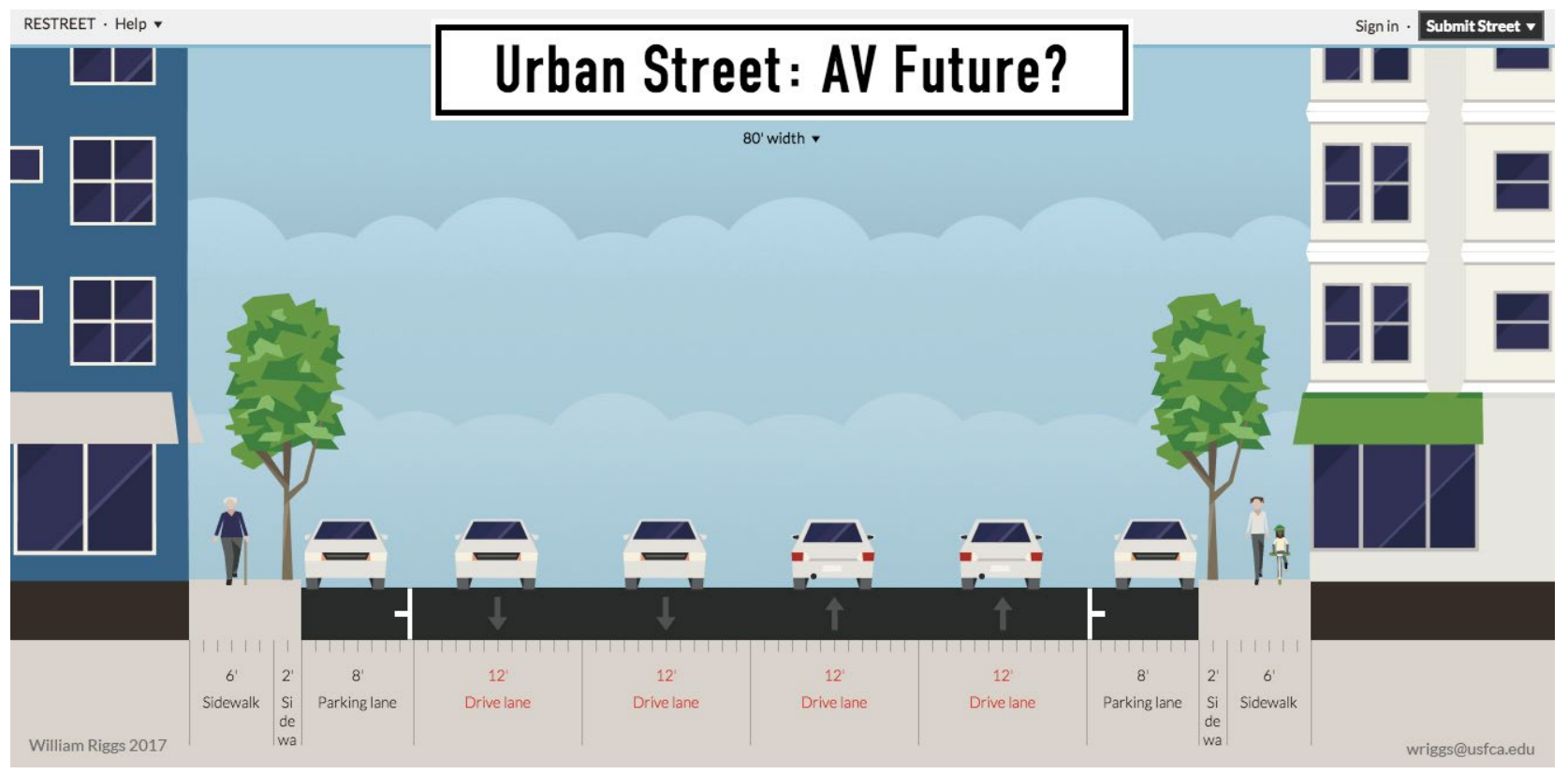

Figure 20. An Evolution of an Urban Street Section in an Era of AVs

Source: William Riggs / ReStreet 


\section{CONCLUSION}

Performance measures and planning support tools are useful only insofar as they help inform agency decisions about future policies, plans, and investments. In particular, performance measures should be defined and measured in order to help communities understand tradeoffs and benefits involved in providing opportunities for people to achieve sustainability, livability, and equity outcomes. Most regions continue to use transportation system performance measures that are dominated by congestion and mobility measures. Although sustainability, livability, and equity are beginning to enter public debate, there appears to be no general consensus on performance measures, what they mean, or how to put them into action.

In sum, informing agency decisions should be the driving force in measures, approaches, study areas, and so on-and a major purpose this work is to help agencies make better, more coordinated transportation and land use decisions. While it would be ideal to have transportation and land use decisions all made by one agency, they are currently led by different agencies operating at different scales and timeframes. Therefore, we are left to develop frameworks to better measure, understand, and then act to realize sustainability, livability, and equity.

In summary, these frameworks should be employed to:

1. Create context-sensitive and inclusive processes to help a community become more sustainable;

2. Help understand what is important to measure and analyze in current conditions and future scenarios; and

3. Screen, prioritize, and mediate strategies in support of increasing a diverse and complementary set of choices and opportunities for greater community sustainability. 


\section{APPENDIX: PERFORMANCE MEASURES}

Building on the above is a discussion, here is a is the set of performance metrics that were recommended for this project. First, they were based on the SMF performance measures and compared to the performance measures used by Metro in the Long Range Transportation Plan (LRTP) as well as by SCAG for the RTP/SCS. In selecting the performance metrics, the intent was to identify a subset of the SMF measures that would be most meaningful in demonstrating the sustainability policies at the sub-regional scale. The authors' approach was built from the six overarching SMF Principles. They are as follows:

- Location Efficiency

- Reliable Mobility

- Health and Safety

- Environmental Stewardship

- Social Equity

- Robust Economy

Alongside these principles were 17 SMF performance measures and their recommended metrics, as described in Exhibit 11 of the Smart Mobility 2010: Call to Action.

The authors' initial assessment was that these SMF measures require that a significant planning analysis infrastructure (e.g. regional travel demand models) already be in place (and accessible) to support the computation of all 17 performance measures, and SMF requires significant investment of professional effort to perform the computations for a variety of possible transportation improvement projects.

Below are the principles from the CSPP and the SBCCOG.

CSPP principles:

- Connect people and places

- Create community value

- Conserve resources

SBCCOG Sustainable South Bay (SSB) principles:

- Reduce criteria pollutants

- Reduce congestion 
- Reduce gasoline consumption

- Improve safety

The specific metrics that are recommended below are intended to be supportive of these principles as well as the overarching principles of the Smart Mobility Framework.

The CSPP uses 15 performance measures in support of the three broad CSPP principles to evaluate projects. Performance measures from CSPP are used for monitoring purposes at the regional level rather than for evaluation or prioritization, but some of them could be appropriate for sub-regional analysis. Additional project-based metrics were developed through consultant efforts related to the CSPP but are meant to be used to compare the performance of different project alternatives rather than to compare and prioritize different projects as part of a sub-regional planning effort. Table 1 lists the metrics used by the CSPP and compares them to the SMF principles.

In addition, the SBCCOG has identified several strategies for sustainable development that would not generally score very well using traditional performance measurement packages, which are often focused on measuring increased system performance for automobiles, which was considered in the selection of performance measures.

Table 1 summarizes the approach, including the recommended performance metrics, tools and data sources.

Table 4. Recommended Performance Metrics

Principles

CSPP

P erfor-
m a n c e $e^{d}$
metric

Average

proximity to

employment

(30 min by

transit)

Average

proximity to

employment

(20 min drive)

Average vehi-

cle occupancy

(AVO)

Modal travel

time and cost

\section{South Bay Cities}

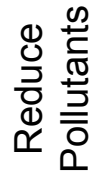

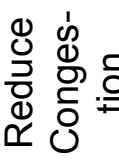

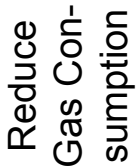

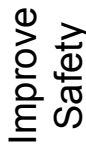


NEV, bicycle, walking facilities

Percentage of trips by transit

Percentage of trips by NEV

Percentage

of trips by

bicycling

Percentage

of trips by

walking

Quantities of criteria pol-

lutants and

GHGs

Vehicle hours

of delay

(VHD) or

person hours

of delay

Vehicle miles

traveled

(VMT) or

person miles

traveled

Vehicle hours

traveled

(VHT)

VMT per

capita by

speed range

Number of

crashes

Number of

vulnerable

user crashes 


\section{BIBLIOGRAPHY}

Ahangari, H., C. Atkinson-Palombo, and N.W. Garrick. Accid Anal Prev 107(2017): 7785.

Appleyard, B. Planning 71(2005).

Appleyard, B., C. Allen, and E. Cordova. 2018. Smart Growth Equity Calculator [WWW Document]. Smart Growth Equity Calculator. Accessed December 12, 2018. http:// smartgrowthcalculator.herokuapp.com/index.html

Appleyard, B., C. Ferrell, C. Allen, C. Schroeder, and C. Armusewicz. Livability Calculator for the TCRP H-45 Handbook, Building Livable Transit Corridors: Methods, Metrics and Strategies. Transit Cooperative Research Program of the Transportation Research Board. Washington, D.C., 2016.

Appleyard, B., C. Ferrell, M. Carroll, and M. Taecker. Transportation Research Record: Journal of the Transportation Research Board 62-71(2014).

Appleyard, B.S., 2011. New Methods to Measure Urban Environments for Consumer Behavior Research| Individual Access Corridor Analysis of Environmentally Sustainable Travel to Rapid Transit. University of California, Berkeley.

Batty, M. "Defining Geodesign (= GIS + Design?)." Environment and Planning B: Planning and Design 40(2013): 1-2.

Boarnet, M., Wang, X., 2018.

Boarnet, Marlon G. and Susan Handy. DRAFT Policy Brief on the Impacts of Residential Density Based on a Review of the Empirical Literature. http://www.arb.ca.gov/cc/ sb375/policies/density/density_brief.pdf

Boarnet, Marlon G. and Susan Handy. DRAFT Technical Background Document on the Impacts of Residential Density Based on a Review of the Empirical Literature. http://www.arb.ca.gov/cc/sb375/policies/density/density_bkgd.pdf

Boarnet, Marlon G., Hsin-Ping Hsu, and Susan Handy. DRAFT Policy Brief on the Impacts of Employer-Based Trip Reduction Based on a Review of the Empirical Literature. http://www.arb.ca.gov/cc/sb375/policies/ebtr/ebtr_brief.pdf

Boarnet, Marlon G., Hsin-Ping Hsu, and Susan Handy. Draft Policy Brief: Impact of JobsHousing Balance on Passenger Vehicle Use and Greenhouse Gas Emissions Based on a Review of the Empirical Literature. http://arb.ca.gov/cc/sb375/policies/ jhbalance/jhbalance_brief.pdf

Boarnet, Marlon G., Kenneth Joh, Wally Siembab, William Fulton, and Mai Thi Nguyen. 2011. Retrofitting the Suburbs to Increase Walking: Evidence from a Land Use- 
Travel Study. Urban Studies (forthcoming). DOI 10.1177/0042098010364859. Cited in Boarnet and Handy [1]

California Air Resources Board. Senate Bill 375: Research on Impacts of Transportation and Land Use-Related Policies. http://arb.ca.gov/cc/sb375/policies/policies.htm

Caltrans, 2010. Smart Mobility.

Cervero, R., 2000. University of California Transportation Center.

Cervero, R., 2001. "Integration of Urban Transport and Urban Planning." In The Challenge of Urban Government: Policies and Practices. World Bank.

Cervero, R., 2003. Built Environment 29(1978): 66-78.

Cervero, R., and M. Duncan. Journal of the American Planning Association 72(2006): 475-490.

Cervero, R., Rood, T., Appleyard, B. Environment and Planning A 31(1999): 1259-1278.

Cinelli, M., Coles, S. R., \& Kirwan, K. (2014). "Analysis of the potentials of multi criteria decision analysis methods to conduct sustainability assessment." Ecological Indicators. http://doi.org/10.1016/j.ecolind.2014.06.011

Dangermond, J. (2010). "GeoDesign and GIS—Designing our Futures." In Peer Reviewed Proceedings of Digital Landscape Architecture. Anhalt University of Applied Science, Germany.

Dowling Associates, Inc. Multimodal Level of Service Measures for Urban Streets. NCHRP Report 616. 2008.

ECONorthwest. Case Study: Testing Application of Integrated Transportation Planning Methods on System Level Evaluation. Report prepared for Puget Sound Regional Council and U.S. Department of Transportation, Federal Highway Administration. June 1996.

ECONorthwest. Integrated Transportation Planning: A Primer for Policymakers. Puget Sound Regional Council. July 1995.

ECONorthwest. Least-Cost Planning: Principles, Applications and Issues. Report prepared for Office of the Environment and Planning, Federal Highway Administration, U.S. Department of Transportation. July 1995.

ECONorthwest. Technical Memorandum Regarding Procedural and Analytical Issues Associated with Implementing Integrated Transportation Planning. Puget Sound Regional Council. June 1995. 
El-Geneidy, A.M., Levinson, D.M., 2006.

Ewing et al. 2010.

Ewing, R., Cervero, R., 2010a. Journal of the American Planning Association 76(2010a): 265-294.

Ewing, R., Cervero, R., 2010b. Journal of the American Planning Association 76(2010b): 265-294.

Ewing, R., Greenwald, M., Zhang, M., Walters, J., Feldman, M., Cervero, R., Frank, L., Thomas, J. Journal of Urban Planning and Development 137(2011): 248-261.

Ewing, R., Hamidi, S., Grace, J.B., Wei, Y.D. Landscape and Urban Planning 148(2016): 80-88.

Exner, J.-P. (2015). "Smart Cities—Field of Application for Planning Support Systems in the 21st Century?" 14th Computers in Urban Planning and Urban Management (CUPUM2015), 118-131.

Ferrell, C.E., Appleyard, B., Taecker, M., 2016. A Handbook for Building Livable Transit Corridors: Methods, Metrics and Strategies. (No. TCRP H-45). Transit Cooperative Research Program.

Flaxman, M. (2009). Fundamentals of Geodesign. Proceedings of Digital Landscape Architecture, 28-41.

Frederick, C., Gilderbloom, J. Local Environment 23(2013): 54-76.

Frederick, C., Riggs, W., Gilderbloom, J.H. International Journal of Sustainable Transportation 12(2018).

Geertman, S., \& Stillwell, J. "Planning Support Systems: An Inventory of Current practice." Computers, Environment and Urban Systems 28(2004): 291-310. http:// doi.org/10.1016/S0198-9715(03)00024-3

Gulden, J., Goates, J., \& Ewing, R. "Mixed-Use Development Trip Generation Model." Transportation Research Record: Journal of the Transportation Research Board 2344(2013): 98-106. http://doi.org/10.3141/2344-11

Hamidi, S., Ewing, R., Tatalovich, Z., Grace, J.B., Berrigan, D. International Journal of Environmental Research and Public Health 15(2018): 861.

Handy, S. International Regional Science Review 28(2005): 146-167.

Handy, Susan, Gian-Claudia Sciara, and Marlon Boarnet. DRAFT Technical Background Document on Impacts of Pedestrian Strategies Based on a Review of the 
Empirical Literature. http://www.arb.ca.gov/cc/sb375/policies/ped/ped_bkgd.pdf

Handy, Susan, Gil Tal, and Marlon Boarnet. DRAFT Policy Brief on the Impacts of Bicycling Strategies Based on a Review of the Empirical Literature. http://www. arb.ca.gov/cc/sb375/policies/bicycling/bicycling_brief.pdf

Handy, Susan, Gil Tal, and Marlon Boarnet. DRAFT Policy Brief on the Impacts of Network Connectivity Based on a Review of the Empirical Literature. http://www. arb.ca.gov/cc/sb375/policies/connectivity/netconnectivity_brief.pdf

Handy, Susan, Gil Tal, and Marlon Boarnet. DRAFT Policy Brief on the Impacts of Regional Accessibility Based on a Review of the Empirical Literature. http://arb. ca.gov/cc/sb375/policies/regaccess/regaccess_brief.pdf

Handy, Susan, Gil Tal, and Marlon Boarnet. DRAFT Policy Brief on the Impacts of Telecommuting Based on a Review of the Empirical Literature. http://www.arb. ca.gov/cc/sb375/policies/telecommuting/telecommuting_brief.pdf

Handy, Susan, Gil Tal, and Marlon Boarnet. DRAFT Technical Background Document on the Impacts of Connectivity Based on a Review of the Empirical Literature. http:// www.arb.ca.gov/cc/sb375/policies/connectivity/netconnectivity_bkgd.pdf

Handy, Susan, Gil Tal, and Marlon Boarnet. DRAFT Technical Background Document on Impacts of Regional Accessibility Based on a Review of the Empirical Literature. http://arb.ca.gov/cc/sb375/policies/regaccess/regaccess_bkgd.pdf

Handy, Susan, Gil Tal, and Marlon Boarnet. DRAFT Technical Background Document on Impacts of Telecommuting Based on a Review of the Empirical Literature. http:// www.arb.ca.gov/cc/sb375/policies/telecommuting/telecommuting_bkgd.pdf

Handy, Susan, Steve Spears, and Marlon G. Boarnet. DRAFT Policy Brief on the Impacts of Transit Service Strategies Based on a Review of the Empirical Literature. http://www.arb.ca.gov/cc/sb375/policies/transitservice/transitservice_ brief.pdf

Handy, Susan, Steve Spears, and Marlon G. Boarnet. DRAFT Technical Background Document on the Impacts of Transit Service Strategies Based on a Review of the Empirical Literature. http://www.arb.ca.gov/cc/sb375/policies/transitservice/ transitservice_bkgd.pdf

Jiang, B., Huang, B., \& Vasek, V. "Geovisualisation for Planning Support Systems." Planning Support Systems in Practice (2003): 177-191. http://doi. org/10.1.1.63.6979

Lachapelle, U., 2010. Public Transit Use as a Catalyst for an Active Lifestyle : Mechanisms, Predispositions and Hindrances. University of British Columbia. 
Lachapelle, U., Frank, L.D. J Public Health Pol 30(2009): S73-S94.

Levine, J., Grengs, J., Shen, Q. Metropolitan Accessibility and Transportation Sustainability: Comparative Indicators for Policy Reform. Presented at the 5th Urban Research Symposium, Marseille, France, 2009.

Levine, J., Grengs, J., Shen, Qingyun, Shen, Qing. Journal of the American Planning Association 78(2012): 157-172.

Levine, Jonathan et al. "Does Accessibility Require Density or Speed?" Journal of the American Planning Association 78(2012, Spring).

Levinson, D.M. Journal of Transport Geography 6(1998): 11-21.

Litman, T. A. (2009). Sustainable Transportation Indicators: A Recommended Research Program For Developing Sustainable Transportation Indicators and Data.

Litman, T., 2016. The Hidden Traffic Safety Solution: Public Transportation.

Malczewski, J. "GIS-based Multicriteria Decision Analysis: A Survey of the Literature." International Journal of Geographical Information Science 20(2006): 703-726. http://doi.org/10.1080/13658810600661508

Malczewski, J., \& Rinner, C. (2015). "Multicriteria Decision Analysis in Geographic Information Science." Advances in Geographic Information Science. http://doi. org/10.1007/978-3-540-74757-4

Mihyeon Jeon, Christy, and Adjo Amekudzi. "Addressing sustainability in transportation systems: definitions, indicators, and metrics."

Moore, T., Thorsnes, P., Appleyard, B., 2007. The Transportation/Land Use Connection, New. ed. American Planning Association (Planners Press).

NCHRP. A Guidebook for Sustainability Performance Measurement for Transportation Agencies. http://www.trb.org/Main/Blurbs/166313.aspx

North Carolina Sustainable Communities Task Force. Presentation to Board of Transportation's Joint Multimodal and Environmental Planning \& Policy Committees. May 4, 2011. http://ncdot.org/download/about/board/eppc/ documents/2011/201105_SCTF_Presentation.pdf

North Carolina (State). Department of Environment and Natural Resources. Sustainable Communities Initiative. http://www.onencnaturally.org/pages/SC_ SustainableCommunities.html

Pei et al. (2010), 
Pei et al. Performance Measurement Frameworks and the Development of Effective Sustainable Transport Strategies and Indicators.

Pennsylvania Department of Transportation and New Jersey Department of Transportation. Smart Transportation Guidebook: Planning and Designing Highways and Streets that Support Sustainable and Livable Communities. March 2008. http://www.state.nj.us/transportation/community/mobility/pdf/ smarttransportationguidebook2008.pdf

Pohekar, S. D., \& Ramachandran, M. Application of Multi-criteria Decision Making to Sustainable Energy Planning: A Review. Renewable and Sustainable Energy Reviews 8(2004): 365-381. http://doi.org/10.1016/j.rser.2003.12.007

Pucher, J., Dill, J. and Handy, S. "Infrastructure, Programs, and Policies to Increase Bicycling: An International Review." Preventive Medicine 50(2010): 106-125. Cited in Handy et al. [15] http://policy.rutgers.edu/faculty/pucher/Pucher_Dill_ Handy10.pdf

Ramini (2010),

Reinke, David and Daniel Malarkey. "Implementing Integrated Transportation Planning in Metropolitan Planning Organization: Procedural and Analytical Issues." Transportation Research Record 1552(1996).

Riggs, W., 2018a. Technology, Civic Engagement and Street Science: Hacking the Future of Participatory Street Design in the Era of Self-Driving Cars (SSRN Scholarly Paper No. ID 3117731). Social Science Research Network, Rochester, NY.

Riggs, W., 2018b. Technology, Civic Engagement and Street Science: Hacking the Future of Participatory Street Design in the Era of Self-driving Cars, in: Proceedings of the 19th Annual International Conference on Digital Government Research: Governance in the Data Age, Dgo '18. ACM, New York, NY, pp. 4:14:6.

Riggs, W.W., 2017.

Sallis, J.F., Cerin, E., Conway, T.L., Adams, M.A., Frank, L.D., Pratt, M., Salvo, D., Schipperijn, J., Smith, G., Cain, K.L., Davey, R., Kerr, J., Lai, P.-C., Mitáš, J., Reis, R., Sarmiento, O.L., Schofield, G., Troelsen, J., Dyck, D.V., Bourdeaudhuij, I.D., Owen, N. The Lancet 387(2016): 2207-2217.

Schlossberg, M., Riggs, W.W., Millard-Ball, A., Shay, E., 2018. UrbanismNext.

Sciara, Gian-Claudia, Susan Handy, and Marlon Boarnet. DRAFT Policy Brief on the Impacts of Pedestrian Strategies Based on a Review of the Empirical Literature. http://www.arb.ca.gov/cc/sb375/policies/ped/ped_brief.pdf 
Solimar Research Group, Inc. South Bay Cities Mixed-Use Guidebook, Version 1.0. July 2007. http://www.southbaycities.org/files/Guidebook\%20Final\%20Draft\%207-1007_0.pdf

Southworth, M. and E. Ben-Joseph. Streets and the Shaping of Towns and Cities. New York: McGraw-Hill, 1997. Cited in Handy et al. [16].

Spears, Steven, Marlon Boarnet, and Susan Handy. DRAFT Policy Brief on the Impacts of Land Use Mix Based on a Review of the Empirical Literature. http://arb.ca.gov/ cc/sb375/policies/mix/landusemix_brief.pdf

Spears, Steven, Marlon Boarnet, and Susan Handy. DRAFT Policy Brief on the Impacts of Parking Pricing Based on a Review of the Empirical Literature. http://www.arb. ca.gov/cc/sb375/policies/pricing/parkingpricing_brief.pdf

Spears, Steven, Marlon Boarnet, and Susan Handy. DRAFT Policy Brief on the Impacts of Road User Pricing Based on a Review of the Empirical Literature. http://www. arb.ca.gov/cc/sb375/policies/pricing/roadpricing_brief.pdf

Spears, Steven, Marlon Boarnet, and Susan Handy. DRAFT Policy Brief on the Impacts of Voluntary Travel Behavior Change Programs Based on a Review of the Empirical Literature. http://www.arb.ca.gov/cc/sb375/policies/vtbc/vtbc_brief.pdf

Spears, Steven, Marlon Boarnet, and Susan Handy. DRAFT Technical Background on the Impacts of Land Use Mix Based on a Review of the Empirical Literature. http:// arb.ca.gov/cc/sb375/policies/mix/landusemix_bkgd.pdf

Spears, Steven, Marlon Boarnet, and Susan Handy. DRAFT Technical Background Document on the Impacts of Parking Pricing Based on a Review of the Empirical Literature. http://www.arb.ca.gov/cc/sb375/policies/pricing/parkingpricing_bkgd. pdf

Spears, Steven, Marlon Boarnet, and Susan Handy. DRAFT Technical Background Document on the Impacts of Road User Pricing Based on a Review of the Empirical Literature. http://www.arb.ca.gov/cc/sb375/policies/pricing/roadpricing_ bkgd.pdf

Spears, Steven, Marlon Boarnet, and Susan Handy. DRAFT Technical Background Document on the Impacts of Voluntary Travel Behavior Change Programs Based on a Review of the Empirical Literature. http://www.arb.ca.gov/cc/sb375/policies/ vtbc/vtbc_bkgd.pdf

Steinitz, C. A Framework for Geodesign: Changing Geography By Design. Redlands, CA: ESRI Press, 2012.

Stimpson, J.P., Wilson, F.A., Araz, O.M., Pagan, J.A. J Urban Health 91(2014): 11361143. 
Tal , Gil, Susan Handy, and Marlon G. Boarnet. DRAFT Policy Brief on the Impacts of Transit Access (Distance to Transit) Based on a Review of the Empirical Literature. http://www.arb.ca.gov/cc/sb375/policies/transitaccess/transitaccess_ brief.pdf

Tal, Gil, Susan Handy, and Marlon G. Boarnet. DRAFT Technical Background Document on the Impacts of Transit Access (Distance to Transit) Based on a Review of the Empirical Literature. http://www.arb.ca.gov/cc/sb375/policies/transitaccess/ transitaccess_bkgd.pdf

Texas A\&M Transportation Institute. "Urban Mobility Report." http://mobility.tamu.edu/ ums/

U.S. Department of Transportation, Federal Highway Administration. Statewide Opportunities for Integrating Operations, Safety and Multimodal Planning: A Reference Manual. May 2010. http://www.fhwa.dot.gov/planning/processes/ statewide/practices/manual/index.cfm

U.S. Department of Transportation, Federal Highway Administration. Transportation Planning for Sustainability Guidebook. January 2011. http://www.fhwa.dot. gov/environment/climate_change/sustainability/resources_and_publications/ guidebook/index.cfm

U.S. Environmental Protection Agency. "Guide to Sustainable Transportation Performance Measures." August 2011. http://www.epa.gov/dced/transpo_ performance.htm

U.S. EPA, O., n.d. "Smart Growth." https://www.epa.gov/smartgrowth (accessed 6.7.16).

Wagner, F., Caves, R. (Eds.). Community Livability: Issues and Approaches to Sustaining the Well-Being of People and Communities. New York: Routledge, 2012.

Washington State Department of Transportation. Gray Notebook. http://www.wsdot. wa.gov/accountability/GrayNotebook.pdf

Washington State Department of Transportation. Performance Measurement Library. http://www.wsdot.wa.gov/Accountability/Publications/Library.htm

Washington State Department of Transportation. WSDOT Accountability \& Performance Information. http://www.wsdot.wa.gov/Accountability/

Zietsman, J. and L. R. Rilett. Sustainable Transportation: Conceptualization and Performance Measures. Southwest Region University Transportation Center, 2002. 
Missing section on sustainability definitions for transportation. There are key features of many definitions that show conceptual agreement. For example:

Black, W. (2005). "Sustainable Transport: Definitions and Responses." Integrating Sustainability into the Transportation Planning Process.

Litman, T. and Burwell, D. (2006). Issues in Sustainable Transportation. International Journal of Global Environmental Issues, 6(4): 331-347.

Zhou, J. (2009). Sustainable Transportation: Review of Proposals, Policies, and Programs 2000-2007. Transportation Research Board 88th Annual Meeting. Washington, DC, Transportation Research Board. 


\section{ABOUT THE PRINCIPAL INVESTIGATOR}

\section{BRUCE APPLEYARD, PHD}

Dr. Bruce Appleyard is an Associate Professor in of City Planning and Urban Design at San Diego State University. He holds a PhD in City \& Regional Planning from UC Berkeley. He is the author of many scholarly articles and serves as the Associate Director of SDSU's Center for the Study of Human Dynamics in our Mobile Age (HDMA), as well as SDSU's Active Transportation Research Center. 


\section{PEER REVIEW}

San José State University, of the California State University system, and the Mineta Transportation Institute (MTI) Board of Trustees have agreed upon a peer review process required for all research published by MTI. The purpose of the review process is to ensure that the results presented are based upon a professionally acceptable research protocol. 


\author{
Founder, Honorable \\ Norman Mineta (Ex-Officio) \\ Secretary (ret.), \\ US Department of Transportation \\ Chair, \\ Abbas Mohaddes (TE 202I) \\ President \& COO \\ Econolite Group Inc. \\ Vice Chair, \\ Will Kempton (TE 2022) \\ Retired \\ Executive Director, \\ Karen Philbrick, PhD \\ (Ex-Officio) \\ Mineta Transportation Institute \\ San José State University \\ Richard Anderson \\ (Ex-Officio) \\ President \& CEO \\ Amtrak \\ David Castagnetti (TE 202 I) \\ Co-Founder \\ Mehlman Castagnetti \\ Rosen \& Thomas \\ Maria Cino (TE 202 I) \\ Vice President \\ America \& U.S. Government \\ Relations Hewlett-Packard Enterprise
}

\author{
Grace Crunican* \\ (TE 2022) \\ Retired
}

Donna DeMartino (TE 202I)

General Manager \& CEO

San Joaquin Regional Transit District

Nuria Fernandez* (TE 2020)

General Manager \& CEO

Santa Clara Valley

Transportation Authority (VTA)

John Flaherty (TE 2020)

Senior Fellow

Silicon Valley American

Leadership Form

Rose Guilbault (TE 2020)

Board Member

Peninsula Corridor

Joint Powers Board

Ian Jefferies (Ex-Officio)

President \& CEO

Association of American Railroads

Diane Woodend Jones

(TE 2022)

Principal \& Chair of Board

Lea + Elliott, Inc.
Therese McMillan

(TE 2022)

Executive Director

Metropolitan Transportation

Commission (MTC)

Bradley Mims (TE 2020)

President \& CEO

Conference of Minority

Transportation Officials (COMTO)

Jeff Morales (TE 2022)

Managing Principal

InfraStrategies, LLC

Dan Moshavi, PhD

(Ex-Officio)

Dean, Lucas College and

Graduate School of Business

San José State University

Takayoshi Oshima (TE 202 I)

Chairman \& CEO

Allied Telesis, Inc.

Toks Omishakin

(Ex-Officio)

Director

California Department of

Transportation (Caltrans)
Paul Skoutelas (Ex-Officio)

President \& CEO

American Public Transportation

Association (APTA)

Dan Smith (TE 2020)

President

Capstone Financial Group, Inc.

Beverley Swaim-Staley (TE 2022)

President

Union Station Redevelopment

Corporation

\section{Jim Tymon (Ex-Officio)}

Executive Director

American Association of

State Highway and Transportation

Officials (AASHTO)

\section{Larry Willis (Ex-Officio)}

President

Transportation Trades

Dept., AFL-CIO

$(\mathrm{TE})=$ Term Expiration

* = Past Chair, Board of Trustees

\section{Directors}

Karen Philbrick, Ph.D.

Executive Director

Hilary Nixon, Ph.D.

Deputy Executive Director

\section{Asha Weinstein Agrawal,}

\section{Ph.D.}

Education Director

National Transportation Finance

Center Director

\section{Brian Michael Jenkins}

National Transportation Security

Center Director

\title{
Research Associates Policy Oversight Committee
}

Jan Botha, Ph.D.

Civil \& Environmental Engineering

San José State University

Katherine Kao Cushing,

\section{Ph.D.}

Enviromental Science

San José State University

Dave Czerwinski, Ph.D. Marketing and Decision Science San José State University
Frances Edwards,

Ph.D.

Political Science

San José State University

Taeho Park, Ph.D.

Organization and Management

San José State University

\section{Christa Bailey}

Martin Luther King, Jr. Library

San José State University

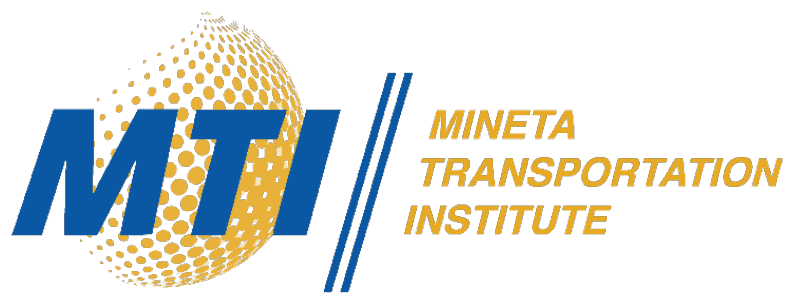

